\title{
Sweet taste receptor expression in ruminant intestine and its activation by artificial sweeteners to regulate glucose absorption
}

\author{
A. W. Moran, ${ }^{*}$ M. Al-Rammahi, ${ }^{* 1}$ C. Zhang, ${ }^{* 2}$ D. Bravo, $†$ S. Calsamiglia,ł and S. P. Shirazi-Beechey ${ }^{* 3}$ \\ *Epithelial Function and Development Group, Institute of Integrative Biology, University of Liverpool, Liverpool L69 7ZB, United Kingdom \\ †Pancosma SA, 1218 Geneva, Switzerland \\ łDepartament de Ciència Animal i dels Aliments, Universitat Autònoma de Barcelona, 08193 Bellaterra, Spain
}

\section{ABSTRACT}

Absorption of glucose from the lumen of the intestine into enterocytes is accomplished by sodium-glucose co-transporter 1 (SGLT1). In the majority of mammalian species, expression (this includes activity) of SGLT1 is upregulated in response to increased dietary monosaccharides. This regulatory pathway is initiated by sensing of luminal sugar by the gut-expressed sweet taste receptor. The objectives of our studies were to determine (1) if the ruminant intestine expresses the sweet taste receptor, which consists of two subunits [taste 1 receptor 2 (T1R2) and 3 (T1R3)], and other key signaling molecules required for SGLT1 upregulation in nonruminant intestines, and (2) whether T1R2T1R3 sensing of artificial sweeteners induces release of glucagon-like peptide-2 (GLP-2) and enhances SGLT1 expression. We found that the small intestine of sheep and cattle express T1R2, T1R3, G-protein gustducin, and GLP-2 in enteroendocrine L-cells. Maintaining 110-d-old ruminating calves for $60 \mathrm{~d}$ on a diet containing a starter concentrate and the artificial sweetener Sucram (consisting of saccharin and neohesperidin dihydrochalcone; Pancosma SA, Geneva, Switzerland) enhances (1) $\mathrm{Na}^{+}$-dependent D-glucose uptake by over 3 -fold, (2) villus height and crypt depth by 1.4- and 1.2fold, and (3) maltase- and alkaline phosphatase-specific activity by 1.5 -fold compared to calves maintained on the same diet without Sucram. No statistically significant differences were observed for rates of intestinal glucose uptake, villus height, crypt depth, or enzyme activities between 50-d-old milk-fed calves and calves maintained on the same diet containing Sucram. When adult cows were kept on a diet containing 80:20 ryegrass hay-to-concentrate supplemented with Sucram, more

\footnotetext{
Received January 31, 2014.

Accepted April 23, 2014.

${ }^{1}$ Present address: Department of Anatomy and Histology, Faculty of Veterinary Medicine, Al-Qadisiyah University, Al-Diwaniyah, Qadisiyah, Iraq.

${ }^{2}$ Present address: School of Life Science, Jiangsu Normal University, 101 Shanghai Road, Tongshan district, Xuzhou, China, 221116.

${ }^{3}$ Corresponding author: spsb@liverpool.ac.uk
}

than a 7-fold increase in SGLT1 protein abundance was noted. Collectively, the data indicate that inclusion of this artificial sweetener enhances SGLT1 expression and mucosal growth in ruminant animals. Exposure of ruminant sheep intestinal segments to saccharin or neohesperidin dihydrochalcone evokes secretion of GLP-2, the gut hormone known to enhance intestinal glucose absorption and mucosal growth. Artificial sweeteners, such as Sucram, at small concentrations are potent activators of T1R2-T1R3 (600-fold > glucose). This, combined with oral bioavailability of T1R2-T1R3 and the understanding that artificial sweetener-induced receptor activation evokes GLP-2 release (thus leading to increased SGLT1 expression and mucosal growth), make this receptor a suitable target for dietary manipulation.

Key words: ruminant, intestine, glucose absorption, taste 1 receptor 2 , taste 1 receptor 3

\section{INTRODUCTION}

Ruminants have evolved a digestive system that enables microbial fermentation of plant structural carbohydrates in the rumen to produce nutrients such as proteins and short-chain FA to fulfil their energy demands. Their digestive system is not designed for efficient utilization of nonstructural carbohydrates, such as starch. However, current feeding practices for ruminants promote the consumption of diets containing high levels of starch to provide the bulk of dietary energy (Walker and Harmon, 1995). Most dietary starch is fermented in the rumen, but, depending on the grain type and the degree of processing, up to $60 \%$ of starch intake may be available in the small intestine for enzymatic hydrolysis by the host (Theurer, 1986; Nocek and Tamminga, 1991; Firkins et al., 2001).

Generally, starch is hydrolyzed in the small intestine of mammalian species by pancreatic $\alpha$-amylase and brush border membrane disaccharidases to glucose (Shirazi-Beechey, 1995). In ruminants, small intestinal digestion of starch to glucose is energetically more efficient than microbial fermentation to short-chain FA 
in the rumen (Owens et al., 1986; Harmon, 2009). It has been proposed that at least $75 \%$ of starch escaping ruminal fermentation must be hydrolyzed and absorbed in the small intestine in order to provide a positive energy contribution to the host, thus avoiding energetically inefficient digestion in the large intestine (Harmon, 2009).

It has been suggested that major factors limiting small intestinal starch utilization by ruminants may include limited activity of pancreatic $\alpha$-amylase or intestinal glucose absorption. Thus, a better understanding of potential limitations to starch digestion and glucose absorption in the intestines of ruminants, and methods to overcome such limitations, is essential for rational formulation of feed in order to maintain animal health and enhance growth, performance, and productivity.

Absorption of glucose in the ruminant small intestine, similar to other mammalian species, is accomplished by the apically located sodium-glucose co-transporter 1 (SGLT1; Shirazi-Beechey, 1995). With rumen development, expression and activity of this protein declines dramatically and becomes negligible in sheep and cow intestines (Wolffram et al., 1986; Shirazi-Beechey et al., 1989, 1991; Lescale-Matys et al., 1993; Wood et al., 2000; Dyer et al., 2003). However, intestinal infusion of ruminant sheep, through duodenal cannulae, with D-glucose and D-galactose (metabolizable substrates of SGLT1), 3-O-methyl $\alpha$, D-glucopyranoside and methyl$\alpha$-D-glucosopyranoside (nonmetabolizable substrates of SGLT1), D-fructose (a monosaccharide not transported by SGLT1), and di(glucose-6-yl)poly(ethylene glycol) ${ }_{600}$ (a membrane impermeable D-glucose analogue), enhanced expression of SGLT1 by over 50 fold (ShiraziBeechey et al., 1991; Lescale-Matys et al., 1993; Wood et al., 2000; Dyer et al., 2003). This indicated that the ruminant intestine maintains the ability to upregulate its capacity to absorb increased luminal glucose, that metabolism of glucose by enterocytes is not responsible for enhanced SGLT1 expression, and that a glucose sensor expressed on the luminal membrane of intestinal epithelial cells initiates pathways controlling glucoseinduced SGLT1 expression (Dyer et al., 2003).

We subsequently showed, for the first time, that the lingual epithelium sweet taste receptor, consisting of 2 subunits, taste 1 receptor 2 (T1R2) and 3 (T1R3), is expressed in mouse intestinal enteroendocrine cells and proposed that it acts as the intestinal glucose sensor (Dyer et al., 2005). The sensor (receptor) functions in association with the G-protein gustducin_(McLaughlin et al., 1992).

Convincing evidence for the involvement of gutexpressed T1R2-T1R3 heteromer and gustducin in intestinal sweet transduction and SGLT1 upregulation was provided by our studies using mice in which the genes for either the $\alpha$-subunit of gustducin (GNAT3) or the T1R3 sweet receptor subunit (Tas1R3) were deleted. The elimination of sweet transduction in mice in vivo prevented the dietary monosaccharide-induced upregulation of SGLT1 expression observed in wild-type mice (Margolskee et al., 2007). Expression of SGLT1 in both types of knockout mice was identical to that of wild-type animals on a low-carbohydrate diet, implying that there is a constitutive pathway independent of luminal glucose sensing by T1R3 and $\alpha$-gustducin, which maintains basal expression of SGLT1 and an inducible pathway dependent on T1R2-T1R3 (Margolskee et al., 2007). Furthermore, when included in the diet of the wild-type mice (Margolskee et al., 2007) or infused directly into the intestine (Stearns et al., 2010), artificial sweeteners also enhanced the expression of SGLT1. In contrast, the knockout mice showed no increase in SGLT1 expression in response to supplementation with sweeteners, indicating that T1R2-T1R3 and $\alpha$-gustducin are required for sensing the presence of sugars and sweeteners in the intestinal lumen (Margolskee et al., 2007).

It is well established that enteroendocrine L-cells, in response to luminal monosaccharides or artificial sweeteners, secrete glucagon-like peptides-1 and -2 (GLP-1 and GLP-2; Rehfeld, 2004; Jang et al., 2007; Sato et al., 2013). Insulin secretion is enhanced by GLP1, whereas GLP-2 increases small intestinal mucosal growth (Drucker et al., 1996). This stimulation of intestinal growth is evidenced by increased crypt depth and villus height (Hartmann et al., 2000; Ramsanahie et al., 2004) and mediated by greater crypt cell proliferation (Drucker et al., 1996), reduced cell apoptosis, and a subsequent increase in the number of villus-differentiated cells (Tsai et al., 1997). It has also been shown that GLP-2 increases SGLT1 expression and intestinal glucose absorption in the rat and pig small intestine (Cheeseman, 1997; Ramsanahie et al., 2003; Cottrell et al., 2006). Our experimental evidence suggests that sensing of monosaccharides and artificial sweeteners by T1R2-T1R3, residing in murine enteroendocrine L-cells, evokes the release of GLP-2, and that this gut hormone enhances SGLT1 expression via a neuro-paracrine pathway in absorptive enterocytes (Shirazi-Beechey et al., 2011).

The major objectives of this study were to assess if (1) cow and sheep intestines express T1R2, T1R3, and other signaling elements required for SGLT1 upregulation, (2) artificial sweeteners included in the diet enhance SGLT1 expression, and (3) glucose and artificial sweeteners evoke GLP-2 release from ruminant intestinal tissue. The AA sequences of cow T1R2 and T1R3 were deduced from the bovine genome. However, due to lack of information on ovine T1R2-T1R3 AA 
sequences in public databases, cDNA encoding for T1R2 and T1R3 was amplified from sheep mRNA, extracted from lingual and intestinal tissues, cloned, and sequenced. We show here that both cow and sheep intestine express T1R2-T1R3, gustducin, and GLP-2 in endocrine L-cells and that the artificial sweetener Sucram (Pancosma SA, Geneva, Switzerland), when included in the diet, enhances SGLT1 expression.

\section{MATERIALS AND METHODS}

\section{Animals}

Calves. Sixteen 10- to 15-d-old bull_Holstein calves were randomly assigned to 1 of 4 treatment groups, housed individually, and cared for under typical commercial conditions. They all received 2 feedings daily, consisting of $2 \mathrm{~L}$ of commercial milk replacer $(20.9 \% \mathrm{CP}$, $19.2 \%$ fat; Exomilk E60, Interjoma SL, Mataro, Spain ) until $50 \mathrm{~d}$ of age. Group $1(\mathrm{n}=4)$ was used as a control (Con 1); group $2(\mathrm{n}=4)$ received the same diet but supplemented with Sucram (an artificial sweetener consisting of saccharin and neohesperidin dihydrochalcone; $400 \mathrm{mg} / \mathrm{kg}$ of DM of milk replacer; SUC 1). Groups 3 and $4(\mathrm{n}=4$ per group) were maintained for additional $60 \mathrm{~d}$ on a commercial starter concentrate $(24 \% \mathrm{CP}$, $19 \%$ crude fat, and $5.5 \%$ crude fiber; Elvor Arranque, Sofiro, St. Brice en Cogles, France) ad libitum, with group 3 acting as controls (Con 2) and the diet of group 4 supplemented with Sucram (200 mg/kg of DM; SUC 2). Milk replacer was provided with free access to the starter diet and water during the milk-feeding period. One week before weaning, milk replacer was reduced to $2 \mathrm{~L}$ daily, and then animals were switched to a starter diet only.

At the end of dietary treatments, 50-d-old (Con 1 and SUC 1) and 110-d-old (Con 2 and SUC 2) calves were anesthetized with sodium pentobarbital and segments of duodenal tissues were removed. Tissues were rinsed in ice-cold saline, cut into small pieces, and fixed in ice-cold $4 \%$ (wt/vol) paraformaldehyde in PBS for $4 \mathrm{~h}$, followed by immersion in 20\% (wt/vol) sucrose (Fluka, Gillingham, UK) in PBS maintained at $4^{\circ} \mathrm{C}$. Remaining tissues were wrapped in aluminum foil, placed in liquid nitrogen and subsequently stored at $-80^{\circ} \mathrm{C}$.

Cows. In a separate experiment, 6 Holstein dairy cows in the dry period (45-60 d before parturition, blocked by calving dates) were randomly assigned to 1 of 2 dietary treatments: a control diet (no addition of Sucram) (Con; 2 cows) and Sucram-supplemented (SUC; 4 cows), which was the same diet as controls but containing Sucram (2 g/cow per d). Cows were fed once daily with a ratio of 80:20 ryegrass hay-toconcentrate diet (the latter consisting of $14.3 \% \mathrm{CP}$,
48.8\% NDF, and 30.7\% ADF on a DM basis), with the dietary design in line with NRC nutritional recommendations (NRC, 2001). Before feeding, Sucram was mixed with $0.5 \mathrm{~kg}$ of the concentrate feed and offered as top dress to the animals in order to ensure full consumption. After $5 \mathrm{~d}$, duodenal biopsies were obtained by surgery under anesthesia. Tissue samples were wrapped in aluminum foil, immersed immediately in liquid nitrogen, and subsequently kept at $-80^{\circ} \mathrm{C}$ or fixed, as described previously. Fixed and frozen tissues from both experiments were sent by express post to the UK laboratory for analysis. All experimental procedures for the studies were approved by the Ethics Committee for Experimental Procedures on Animals of the Universitat Autonoma de Barcelona.

Sheep. Four sheep ( 3 -yr-old, pure Lleyn breed) were euthanized with an intravenous injection of 20 $\mathrm{mL}$ of sodium pentobarbitone $(200 \mathrm{mg} / \mathrm{mL}$, Pentoject, AnimalCare Ltd, York, UK), in line with schedule 1 UK Home Office regulations and approved by the University of Liverpool Ethics Committee. Intestinal tissue samples were removed promptly after euthanasia. Sections of small intestine, $\sim 20 \mathrm{~cm}$ in length, were removed from the duodenum jejunum and ileum. Fresh $\sim 2$-cm sections of intestine were used immediately for gut hormone measurements, with 1- to 2-cm sections from each region fixed as described previously for histological and immunohistochemical analyses. Sections of sheep tongue were also cut into $\sim 1$-cm pieces, frozen in liquid nitrogen, and stored at $-80^{\circ} \mathrm{C}$ until used for RNA extraction. Histological examination of bovine and ovine intestinal tissues revealed that tissues were intact with epithelial cells attached.

\section{Cloning of Ovine Tas1R2 and Tas1R3}

Total RNA was isolated from ovine tongue and intestinal tissues using peqGOLD total RNA isolation kit with on-column DNase 1 digestion (PEQLab, Hampshire, UK). The RNA was quantified by UV spectrophotometry [assuming an optical density reading at 260 $\mathrm{nm}\left(\mathrm{OD}_{260}\right)$ that gives a value of $\left.1=40 \mu \mathrm{g} / \mathrm{mL}\right] \mathrm{O}$ and integrity determined by gel electrophoresis. Complementary DNA was prepared using random hexamer primers and superscript III reverse transcriptase (Life Technologies, Paisley, UK), purified using QiaQuick PCR purification kit (Qiagen, Crawley, West Sussex, UK), and quantified by UV spectrophotometry (assuming an $\mathrm{OD}_{260}$ value of $1=33 \mu \mathrm{g} / \mathrm{mL}$ ). Consensus primers designed to cow, human, pig, and mouse T1R2 and T1R3 sequences, purchased from Eurogentec (Seraing, Belgium), are listed in Table 1. Polymerase chain reactions were performed using consensus primers (final concentration of $0.2 \mu M$ ), velocity DNA polymerase 
Table 1. List of primers

\begin{tabular}{llc}
\hline & & \\
Primer name & Sequence & $\begin{array}{c}\text { Melting temperature } \\
\left({ }^{\circ} \mathrm{C}\right)\end{array}$ \\
\hline Ovine taste 1 receptor 2 & & \\
Sense primer 1 & 5'-TTCCGCTGGAATTGGATCGT-3' & 56.7 \\
Antisense primer 1 & 5'-GTTGAAGGACTCGGTGGTGT-3' & 51.1 \\
Sense primer 2 & 5'-CTGCTTCACCGTCTGCATCT-3' & 52.7 \\
Antisense primer 2 & 5'-CTAGTCCTTCCGCATGGTG-3' & 50.4 \\
Ovine taste 1 receptor 3 & & \\
Sense primer 1 & 5'-CAACCGCGAGACGTTCCCATC-3' & 61.1 \\
Antisense primer 1 & 5'-GCTCCATGCCCGGTAGTGTCA-3' & 59.4 \\
Sense primer 2 & 5'-TCCATTCCTGCTGCTACGAC-3' & 52.7 \\
Antisense primer 2 & 5'-TCACTTGTTTTTCCCCTGAGTCTC-3' & 55.4 \\
\hline
\end{tabular}

(2.5 unit; Bioline, Essex, UK), and $50 \mathrm{ng}$ of cDNA as template in a $50-\mu \mathrm{L}$ reaction. The cycling conditions were an initial denaturation of $95^{\circ} \mathrm{C}$ for $2 \mathrm{~min}$, followed by 25 cycles of $95^{\circ} \mathrm{C}$ for $15 \mathrm{~s}$, and annealing for $15 \mathrm{~s}$ at $72^{\circ} \mathrm{C}$ for $30 \mathrm{~s}$. The annealing temperatures were $5^{\circ} \mathrm{C}$ below the lowest primer temperature. The PCR products were gel purified on $1 \%$ agarose gels, cloned into pGEM-T Easy vector (Promega, Southampton, UK), and custom sequenced (Eurofins-MWG, Ebersberg, Germany). Sequence alignments were performed using commercial software (Vector NTi, Life Technologies).

\section{Quantitative PCR}

Relative mRNA expression in the intestine of calves maintained on different diets was determined by quantitative real-time reverse transcription PCR. The RNA, isolated from bovine small intestinal tissue and quantified as described previously, was used as template for first-strand cDNA synthesis. Purified cDNA quantified by UV spectrophotometry was diluted to $5 \mathrm{ng} /$ $\mu \mathrm{L}$. Primers to bovine SGLT1 (bSGLT1; sense primer $=5^{\prime}$-AAGGCGGGGGTGGTGACGAT-3'; antisense primer $=5^{\prime}$-CGCCAGGCCCCCTGTGATTG-3' ${ }^{\prime}$, and RNA polymerase II ( $\mathrm{b} P O L R 2 A$; sense primer $=5^{\prime}$-TGCGCTGCATCGAGTCCAACAT-3'; antisense primer = 5'-GGCTCACGCCGTCCGTCTC-3') were designed using Primer-BLAST (Ye et al., 2012) and purchased from Eurogentec. Each PCR reaction consisted of 25 ng of cDNA template, $1 \times$ SYBR green JumpStart Taq ReadyMix (Sigma-Aldrich, Poole, Dorset, UK), and $900 \mathrm{n} M$ of each primer in a total volume of $25 \mu \mathrm{L}$. The PCR cycling consisted of initial denaturation at $95^{\circ} \mathrm{C}$ for $2 \mathrm{~min}$ followed by 45 cycles of $95^{\circ} \mathrm{C}$ for $15 \mathrm{~s}$ and $60^{\circ} \mathrm{C}$ for $1 \mathrm{~min}$. Assays were performed in triplicate using a RotorGene 3000 (Qiagen) with relative abundance calculated using RG-3000 comparative quantification software (Qiagen). The abundance of SGLT1 mRNA was normalized to that of RNA polymerase II; expression of RNA polymerase II did not change throughout the experiments. Routinely, PCR assays without using reverse transcriptase were employed and indicated a lack of any DNA contamination. Melt curve analysis showed no primer dimer formation in the assays. The PCR amplification efficiencies for all genes ranged between 86 and $92 \%$, with a mean efficiency of $89 \%$.

\section{Morphometry}

Morphometric analysis was performed on 10- $\mu$ m thick sections of calf duodenal tissues. As described previously (Moran et al., 2010b), the sections were exposed to tap water for 1 min, transferred to Mayer's Haemalum (3.3 $\mathrm{m} M$ Mayer's Haemalum-haematoxylin, $1 \mathrm{~m} M$ sodium iodate, $0.42 \mathrm{~m} M$ potassium alum; Sigma-Aldrich) for 1 min, and washed gently with running tap water for 5 min. They were stained with eosin Y solution $[1 \%$ (wt/ vol) eosin aqueous; HD Supplies, Buckingham, UK] for $30 \mathrm{~s}$ and subsequently dehydrated by step-wise washing in $70 \%$ ethanol (vol/vol) for $2 \times 1$-min intervals, absolute ethanol for $2 \times 1$-min intervals, and xylene for $3 \times 1$-min intervals, before mounting with DPX neutral mounting medium (Sigma-Aldrich).

Digital images were captured with an Eclipse E400 microscope and DXM 1200 digital camera (Nikon, Kingston upon Thames, Surrey, UK), analyzed using ImageJ software (National Institutes of Health, Bethesda, MD), and calibrated using a $100-\mu \mathrm{m}$ gradient slide. The crypt depth and the villus height were measured as the average distance from crypt base to crypt-villus junction and villus base to villus tip, respectively. The villus height and the crypt depth measurements were taken from an average of 16 well-oriented crypt-villus units. A minimum of 3 images were captured per section, with a minimum of 8 sections prepared per animal. All images were captured under the same conditions with care taken to ensure that the same villus was not counted twice.

\section{Immunohistochemistry}

Sheep and cow small intestinal tissues used for immunohistochemical studies were processed in an identical 
manner. Fixed and cryoprotected tissue samples were embedded in gelatin and frozen in liquid nitrogen-cooled isopentane before sectioning on a cryostat (Leica, CM 1900UV-1-1, Milton Keynes, UK). Serial sections ( $8-\mu \mathrm{m}$ thick) thaw-mounted onto polylysine-coated slides were washed for $5 \times 5$ min in PBS before nonspecific binding sites were blocked using antibody-specific blocking solutions for $1 \mathrm{~h}$ at room temperature. For procedures using antibodies to T1R2, T1R3, and $\alpha$-gustducin, blocking solution containing 5\% (wt/vol) sucrose, $3 \%$ (wt/vol) BSA, $2 \%$ (vol/vol) donkey serum, and $0.1 \%$ (wt/vol) $\mathrm{NaN}_{3}$ in PBS was used. When using antibodies to GLP-2, the blocking solution consisted of $3 \%$ (wt/ vol) BSA, 2\% (vol/vol) donkey serum, and $0.1 \%$ (wt/ vol) $\mathrm{NaN}_{3}$ in PBS; for antibodies to chromogranin A (a classical marker of enteroendocrine cells), the blocking solution contained $10 \%$ (vol/vol) donkey serum in PBS. A number of primary antibodies raised in different species were used for single and double immunolabelling. A monoclonal antibody (ab8204; Abcam Ltd, Cambridge, UK) to chromogranin A was used at a dilution of 1:100. Antibodies to T1R2 (H-90; raised in rabbits) and T1R3 (N-20; raised in goats) were both used at dilutions of 1:750. The antibody to $\alpha$-gustducin (I-20; raised in rabbits) was used at a dilution of 1:300, whereas the GLP-2 antibody (C-20; raised in goats) was diluted 1:100. These antibodies were purchased from Santa Cruz Biotechnology (Wembley, Middlesex, UK). The composition of the buffer containing antibodies (primary and secondary) was $2.5 \%$ ( vol/vol) donkey serum, $0.25 \%$ (wt/vol) $\mathrm{NaN}_{3}$, and $0.2 \%$ (vol/vol) triton X-100 in PBS. For double immunostaining, tissues were incubated at $4^{\circ} \mathrm{C}$ overnight with primary antibodies raised in different species; antibodies were mixed with one another without changing the required final concentration. Following incubation with primary antibodies, slides were washed with PBS followed by staining with fluorochrome-labelled cyanine 3- or fluorescein isothiocyanate-conjugated anti-rabbit/ anti-goat/anti-mouse IgG (Jackson ImmunoReseach, Newmarket, UK) at a dilution of 1:500 for $1 \mathrm{~h}$ at room temperature. Sections were washed thoroughly with PBS, as described previously, before mounting with Vectashield Hard Mounting Medium (Vector Laboratories Limited, Peterborough, UK). The sections were visualized using an epifluorescence microscope (Nikon) and images were captured with a Hamamatsu digital camera (C4742-96-12G04, Hamamatsu Photonics K.K., Hamamatsu City, Japan). Images from double immunohistochemistry were merged using Imaging Products Laboratory imaging software (BioVision Technologies, Exton, PA). Specificity of antibodies has been verified in our previous studies (Moran et al., 2010a; Batchelor et al., 2011; Daly et al., 2013). However, omission of primary antibody was routinely used as a further control.

\section{Preparation of Brush Border Membrane Vesicles}

Brush border membrane vesicles (BBMV) were isolated from bovine duodenal tissues based on the procedure described by Shirazi-Beechey et al. (1990), with modifications outlined by Rowell-Schäfer et al. (1999) and Dyer et al. (2003). All steps were carried out at $4^{\circ} \mathrm{C}$. Tissues were thawed in a buffer solution $(100 \mathrm{mM}$ mannitol, $2 \mathrm{~m} M$ HEPES/Tris, $\mathrm{pH} 7.1$, with protease inhibitors, $0.5 \mathrm{~m} M$ dithiothreitol, $0.2 \mathrm{~m} M$ benzamidine, and $0.2 \mathrm{~m} M$ phenolmethylsulfonyl fluoride), cut into small pieces, and vibrated for $1 \mathrm{~min}$ at maximum speed using a Vibromixer (Alpha Laval, Camberley, Surey, UK) in order to free epithelial cells. Subsequently, the suspension was filtered through a Büchner funnel (Thermo Scientific Nalgene, Hemel Hempstead, UK) to remove any muscle and connective tissues. The filtrate was then homogenized using a Polytron (Ystral, Reading, UK) for $2 \times 30 \mathrm{~s}$. The resulting homogenate was then filtered through 2 layers of nylon gauze. Next, $\mathrm{MgCl}_{2}$ was added to a final concentration of $10 \mathrm{mM}$ and the solution stirred on ice for $20 \mathrm{~min}$. The suspension was then centrifuged for $10 \mathrm{~min}$ at $3,000 \times g$ (SS34 rotor, Sorvall, UK) and the resulting supernatant was spun for $30 \mathrm{~min}$ at $30,000 \times \mathrm{g}$. The pellet was suspended in buffer $\left(100 \mathrm{~m} M\right.$ mannitol, $0.1 \mathrm{~m} M \mathrm{MgSO}_{4}$, and $20 \mathrm{~m} M$ HEPES/Tris, $\mathrm{pH}$ 7.1) and homogenized with 10 strokes of a Potter Elvehjem Teflon hand-held homogenizer (Sigma-Aldrich, Poole, UK) before centrifuging for $30 \mathrm{~min}$ at $30,000 \times g$ at $4^{\circ} \mathrm{C}$. The final pellet was resuspended in an isotonic buffer solution $(300 \mathrm{mM}$ mannitol, $0.1 \mathrm{~m} \mathrm{M} \mathrm{MgSO}_{4}$, and $20 \mathrm{~m} M$ HEPES/Tris, $\mathrm{pH}$ 7.4) and homogenized by passing through a 27 -gauge needle several times. The protein concentration in the BBMV was estimated by its ability to bind Coomassie blue according to the Bio-Rad assay technique (BioRad, Hemel Hempstead, UK). Porcine $\gamma$-globulin was used as the standard. Inclusion of protease inhibitors in the buffers is essential for avoiding SGLT1 protein degradation.

In preparation for Western blot analysis, aliquots of freshly prepared BBMV were diluted with sample buffer $[62.5 \mathrm{~m} M$ Tris/HCl, pH 6.8, $10 \%$ (vol/vol) glycerol, $2 \%$ (wt/vol) SDS, $0.05 \%$ (vol/vol) $\beta$-mercaptoethanol, $0.05 \%$ (wt/vol) bromophenol blue] and stored at $-20^{\circ} \mathrm{C}$ until use. The remaining BBMV were divided into aliquots and stored in liquid nitrogen until use for glucose uptake studies.

\section{Western Blotting}

The abundance of SGLT1 and $\beta$-actin proteins in the BBMV isolated from bovine duodenum was determined by Western blotting, as described previously (Dyer et 
al., 2003; Moran et al., 2010b). Protein components of BBMV were separated by SDS-PAGE on $8 \%$ (wt/ vol) polyacrylamide mini gels, containing $0.1 \%$ (wt/ vol) SDS, and electrotransferred to polyvinyldifluoride (PVDF) membrane (Immun-Blot, Bio-Rad). The PVDF membranes were blocked by incubating for $1 \mathrm{~h}$ at room temperature in PBS-TM buffer [PBS containing $0.05 \%$ (vol/vol) Tween-20 and $0.5 \%$ (wt/vol) nonfat dried milk] before incubation with SGLT1 antibody diluted 1:1,000 in PBS-TM.

The antibody to SGLT1 was raised in rabbits (custom synthesis) to a recombinant peptide corresponding to amino acids 554 to 639 of ovine SGLT1 protein sharing $96.5 \%$ homology to bovine SGLT1 sequence (Wood et al., 2000; Dyer et al., 2009). Immunoreactive bands were detected by incubation for $1 \mathrm{~h}$ with affinitypurified horseradish peroxidase-linked anti-rabbit secondary antibody (Dako Ltd, Cambridge, UK), diluted 1:2,000 in PBS-TM, and visualized using West-one Western blot detection system (iNtRON Biotechnology, Chembio Ltd., Hertfordshire, UK) and Bio-Max Light Chemiluminescence Film (Sigma-Aldrich). The intensity of the immunoreactive bands was quantified using scanning densitometry (Phoretix 1D quantifier, Nonlinear Dynamics, Newcastle upon Tyne, UK).

The PVDF membranes were stripped by $3 \times 10$ min washes in $137 \mathrm{~m} M \mathrm{NaCl}, 20 \mathrm{~m} M$ glycine $/ \mathrm{HCl}(\mathrm{pH}$ 2.5 ) and then reprobed with a monoclonal antibody to $\beta$-actin (clone AC-15, diluted 1:20,000; Sigma-Aldrich); used as a loading control. Blocking solution consisted of $5 \%(\mathrm{wt} / \mathrm{vol})$ skimmed milk powder, $0.1 \%$ ( $\mathrm{vol} / \mathrm{vol})$ Triton X-100, and $0.1 \mathrm{~m} M$ EDTA in PBS. Incubation and washing buffers were made up of $0.1 \%$ (vol/vol) Triton X-100 and $0.1 \mathrm{~m} M$ EDTA in PBS (PBS-TE). Horseradish peroxidase-linked anti-mouse secondary antibody (DAKO Ltd) diluted 1:2,000 in PBS-TE was used and visualized, as described previously.

\section{Measurement of $\mathrm{Na}^{+}-$Dependent Glucose Uptake}

Sodium-dependent glucose uptake into BBMV was measured as described (Shirazi-Beechey et al., 1990; Moran et al., 2010b). The uptake of D-glucose was initiated by the addition of $100 \mu \mathrm{L}$ of incubation medium [100 m $M$ sodium thiocyanate, NaSCN (or potassium thiocyanate, KSCN), $100 \mathrm{~m} M$ mannitol, $20 \mathrm{mM}$ HEPES/Tris (pH 7.4), $0.1 \mathrm{mM} \mathrm{MgSO}_{4}, 0.02 \%$ (wt/vol) $\mathrm{NaN}_{3}$, and $0.1 \mathrm{mM}\left(\mathrm{U}_{-}{ }^{14} \mathrm{C}\right)$-D-glucose $(10.6 \mathrm{GBq} / \mathrm{mmol}$, Perkin Elmer, Seer Green, Bucks, UK)] to BBMV (100 $\mu \mathrm{g}$ of protein) at $37^{\circ} \mathrm{C}$. The reaction was stopped after $3 \mathrm{~s}$ by the addition of $1 \mathrm{~mL}$ of ice-cold stop buffer [150 mM KCl, $20 \mathrm{~m} M$ HEPES/Tris (pH 7.4), $0.1 \mathrm{~m} M$ $\mathrm{MgSO}_{4}, 0.02 \%$ (wt/vol) $\mathrm{NaN}_{3}$, and $0.1 \mathrm{~m} M$ phlorizin]. Aliquots $(0.9 \mathrm{~mL})$ of the reaction mixture were removed and filtered under vacuum through a $0.22-\mu \mathrm{m}$ pore cellulose acetate or nitrate filter (GSTF02500, Millipore, Hertfordshire, UK). The filter was washed with $5 \times 1$ $\mathrm{mL}$ of ice-cold stop buffer, placed in a vial containing 4 $\mathrm{mL}$ of scintillation fluid (Scintisafe 3, Fisher Scientific, Loughborough, UK), and the radioactivity retained on the filter was measured using an LS 6500 multipurpose scintillation counter (Beckman-Coulter, High Wycombe, UK). All uptakes were measured in triplicate.

\section{Enzyme Assays}

Maltase activity was measured based on the method described by Dahlqvist (1964), whereas the activity of alkaline phosphatase was determined according to the method of Shirazi et al., (1981). Brush border membrane vesicles were initially diluted 1:100 with buffer [300 $\mathrm{m} M$ mannitol, $20 \mathrm{~m} M$ HEPES/Tris ( $\mathrm{pH}$ 7.4), $\left.0.1 \mathrm{mM} \mathrm{MgSO}_{4}\right]$. For maltase determination, diluted BBMV $(50 \mu \mathrm{L})$ were incubated at $37^{\circ} \mathrm{C}$ in $50 \mu \mathrm{L}$ of reaction buffer [56 $\mathrm{m} M$ maltose and $100 \mathrm{~m} M$ Na maleate $(\mathrm{pH} \mathrm{6.0)]} \mathrm{for} 15 \mathrm{~min}$. Reactions were stopped by immersing the tubes in boiling water for $2 \mathrm{~min}$. Concentration of released glucose in each reaction mixture was measured using a commercial kit (Roche, Burgess Hill, West Sussex, UK). Maltase-specific activity was calculated as nanomoles per minute per milligram of brush border membrane protein.

For alkaline phosphatase measurements, assay buffer was prepared by mixing buffer $\left[0.1 \mathrm{mM} \mathrm{MgSO}_{4}, 100\right.$ $\mathrm{m} M \mathrm{Na}_{2} \mathrm{CO}_{3} / \mathrm{NaHCO}_{3}(\mathrm{pH}$ 10)] with substrate $(10 \mathrm{~m} M$ p-nitrophenolphosphate; Fluka, Poole, Dorset, UK) in a 10:1 ratio. The reaction was started by the addition of $1 \mathrm{~mL}$ of assay buffer to $50 \mu \mathrm{L}$ of diluted BBMV and incubating at $37^{\circ} \mathrm{C}$ for $15 \mathrm{~min}$. The reaction was stopped by the addition of $1 \mathrm{~mL}$ of $0.5 \mathrm{M} \mathrm{NaOH}$. The absorbance of released $p$-nitrophenol was measured at $400 \mathrm{~nm}$ (Hitachi U-2000 spectrophotometer, Intel MS, Leixlip, Co. Kildare, Ireland) and the alkaline phosphatase specific activity (nanomoles per minute per milligram of protein) was calculated using the millimolar extinction coefficient $=17 \mathrm{mM}$.

\section{Gut Hormone Secretion Measurements}

Freshly removed sections of sheep duodenum, jejunum, and ileum $(\sim 2 \mathrm{~cm})$ were prepared and treated as described previously (Daly et al., 2013). Briefly, sections were incubated at $37^{\circ} \mathrm{C}$ in incubation media [Dulbecco's modified Eagle's medium (5.55 mM D-glucose; Sigma-Aldrich) with $10 \%$ (vol/vol) fetal bovine serum, $2 \mathrm{~m} M$ L-glutamine, $100 \mathrm{U} / \mathrm{mL}$ of penicillin, $100 \mu \mathrm{g} / \mathrm{mL}$ of streptomycin, $20 \mu \mathrm{L} / \mathrm{mL}$ of dipeptidyl peptidase- 4 (DPPIV) inhibitor (Millipore, Watford, UK)] supple- 
mented with either $300 \mathrm{~m} M$ D-glucose, $300 \mathrm{~m} M$ mannitol, or $5 \mathrm{~m} M$ each of the artificial sweeteners, sucralose, saccharin, or neohesperidin dihydrochalcone (NHDC). Control tissues were maintained simultaneously in incubation media without supplementation. After $1 \mathrm{~h}$, incubation media were collected, centrifuged to remove cell debris, and stored at $-80{ }^{\circ} \mathrm{C}$. Cellular and tissue integrity were assessed as described previously (Daly et al., 2013). Levels of secreted GLP-2 in the media were determined using commercial enzyme immunoassay kits (Phoenix Pharmaceuticals, Phoenix Europe GmbH, Karlsruhe, Germany) following manufacturer instructions. Samples were assayed in duplicate and calibrator samples were included in each assay. The intraassay variation was $\pm 6 \%$. Standard curves were constructed using GraphPad Prism 5 (GraphPad Software Inc., La Jolla, CA). The DPPIV inhibitor was included in the incubation media to avoid degradation of GLP-2 by the enzyme DPPIV present in the intestinal tissue. Mannitol was used as a control to determine any potential effect of osmolarity.

\section{Statistical Analysis}

For comparison of SGLT1 expression, maltase and alkaline phosphatase activity, and measurements of crypt depth or villus height in intestinal tissues of animals kept as controls or fed diets containing Sucram, oneway ANOVA (GraphPad Prism 5, GraphPad Software Inc.) with Dunnett's multiple comparison post-test was used. For assessing differences in levels of GLP-2 release from ovine intestinal tissues in response to D-glucose or artificial sweetener compared to untreated control, oneway ANOVA with Bonferroni's multiple comparison post-test was used. The level of statistical significance was set at $P<0.05$.

\section{RESULTS}

\section{Cloning of T1R2 and T1R3 from Ovine Lingual and Intestinal Epithelia}

The PCR amplicons, produced from RNA isolated from sheep lingual and intestinal epithelia, were cloned and sequenced. Two separate fragments specific for T1R2, 522 and $348 \mathrm{bp}$ in length, respectively, were screened against the National Center for Biotechnology Information nonredundant nucleotide database, via BlastN (Zhang et al., 2000), identifying the cloned sequences as homologous to T1R2 in many other mammalian species. The two fragments of sheep T1R2 had 94.6 and $96 \%$ homology to the cow T1R2 sequence, 85.4 and $90.5 \%$ homology to the pig T1R2 sequence, 83.7 and $89.1 \%$ homology to the human T1R2 sequence, and
77.1 and $84.2 \%$ to the mouse T1R2 sequence. A 966-bp fragment, obtained using T1R3-specific primers, was identified as being homologous to T1R3 in many other species. The sheep T1R3 fragment shows 95.2, 82.8, 79.7 , and $74.4 \%$ sequence homology to cow, pig, human, and mouse T1R3, respectively. The National Center for Biotechnology Information accession numbers for the mRNA sequences of ovine T1R2 and T1R3 are KC469057 and KC469056, respectively.

The cloned cDNA fragments were translated to produce sequences of 174 and 115 AA (corresponding to residues 201 to 372 and 723 to 838 of cow T1R2) and 321 AA (corresponding to residues 510 to 831 of cow T1R3). The data indicate that ovine lingual and intestinal epithelia express T1R2 and T1R3 mRNA. The AA residues, aligned using commercial software (Vector NTi; Life Technologies) to the corresponding regions in cow, pig, human, and mouse T1R2 and T1R3 (Figure 1 and 2), show a high degree of homology to cow, human, mouse, and pig sequences. The two fragments of sheep T1R2 have 94.8 and $99.1 \%$ homology to the cow T1R2 sequence. The sheep T1R3 fragment shows $97.2 \%$ sequence homology to cow T1R3.

\section{Expression of T1R2 and T1R3 Proteins in the Ovine Small Intestine}

By immunohistochemistry, we show that the sweet receptor subunits, T1R2 and T1R3, along with $\alpha$-gustducin, are expressed in the ovine small intestine (Figure 3). Cells possessing T1R2, T1R3, and $\alpha$-gustducin have a characteristic flask-shaped feature indicative of being enteroendocrine cells. This was confirmed by showing that these cells also express chromogranin A. The pattern of expression for T1R2, T1R3, and $\alpha$-gustducin were similar along the longitudinal axis of ovine small intestine (data not shown). Collectively, the data demonstrate that the ovine intestine expresses both mRNA and protein for T1R2 and T1R3.

\section{Expression of T1R2, T1R3, a-Gustducin, and GLP-2 in the Bovine Small Intestine}

As shown in Figure 4A, T1R2, T1R3, and $\alpha$-gustducin are co-expressed with chromogranin A, demonstrating that the sweet receptor signaling components reside in enteroendocrine cells of bovine duodenum. Furthermore, Figure 4B shows that T1R2 is co-expressed with GLP-2. Similar patterns of co-expression for T1R3 and GLP-2 were observed (data not shown). This indicates that T1R2 and T1R3 are expressed in L-endocrine cells, as shown in other species (Margolskee et al., 2007; Moran et al., 2010a; Batchelor et al., 2011; Daly et al., 2012). Moreover, the data confirm that endocrine cells 
A

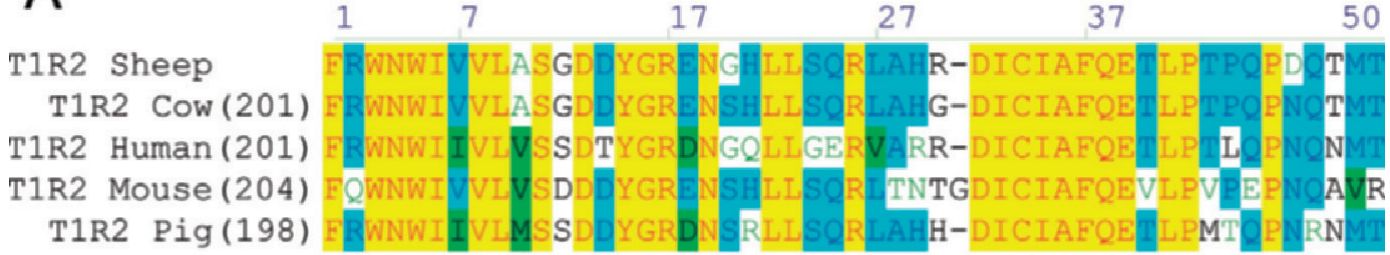

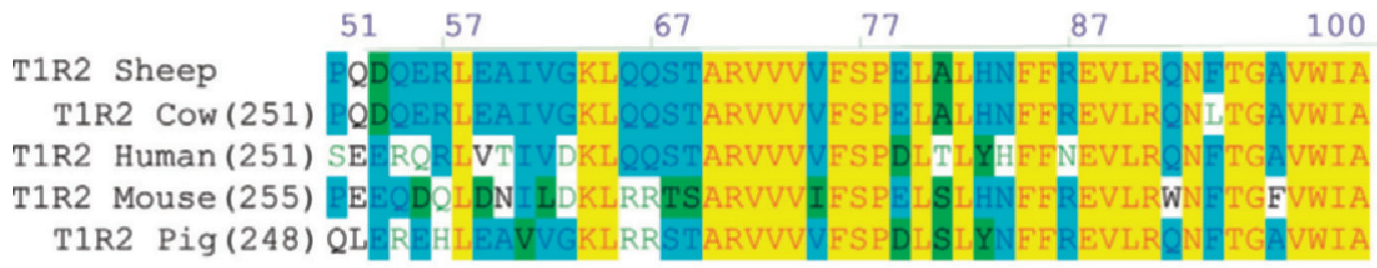

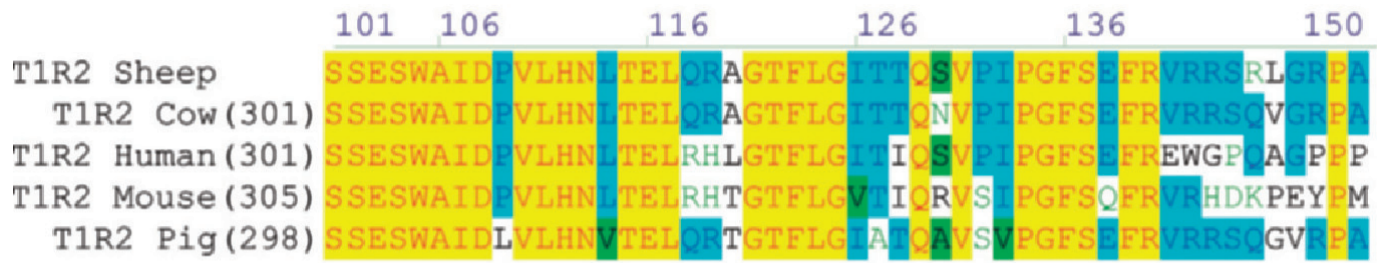

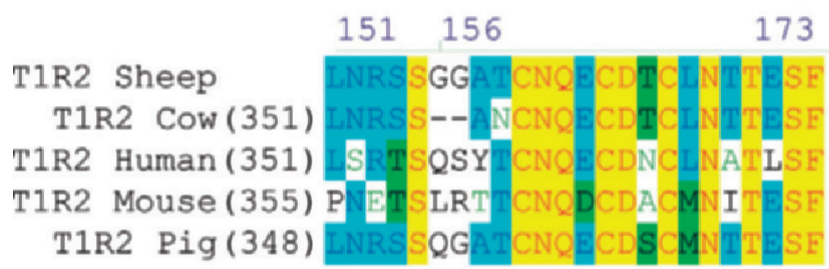

\section{B} T1R2 Sheep T1R2 Cow (723) T1R2 Human (725) RNSLLFNTS T1R2 Mouse (729) RN FLLFNTSM 12 22 32 49
KEITECMTEMESS
KEITECMTEYFSSS
KEITLSMTFYFISS
KEITLSMTESFISS 1 (1) YTGKELPTNYNEAKE T1R2 Pig (721) HRGLIINTS LDLFLSVIGFGFAYVGKELPTNYNEAKFITECMTFYFISS

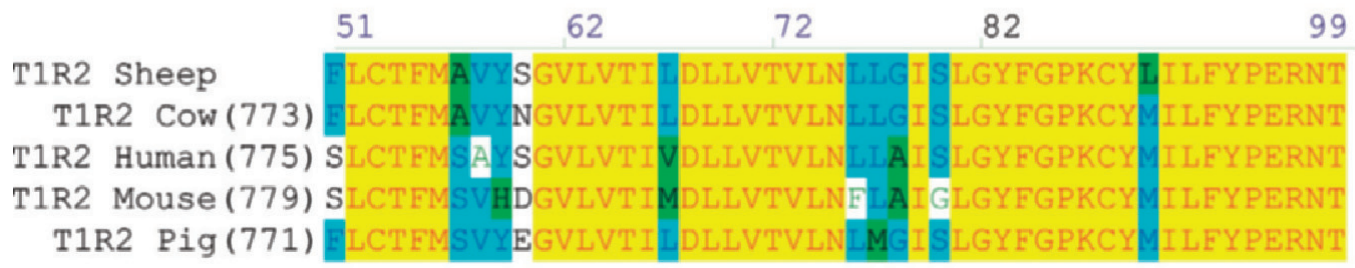

T1R2 Sheep 101
AYFNS IQGYTMRKD
T1R2 Cow (823) AYFNS IQGYTMR
T1R2 Human (825) AYFNSMIQGYTMR
T1R2 Mouse (829) AYFNSMIQGYTMR S
T1R2 Pig (821) AYFNS IQGYTMRR

Figure 1. Alignment of ovine taste 1 receptor 2 (T1R2) AA sequence for (A) 174 and (B) 115 AA fragments deduced from the cloned mRNA nucleotide sequence, with the corresponding regions of cow, pig, human, and mouse T1R2 (numbers in parentheses relate to initiating Met residue). Color version available in the online PDF. 


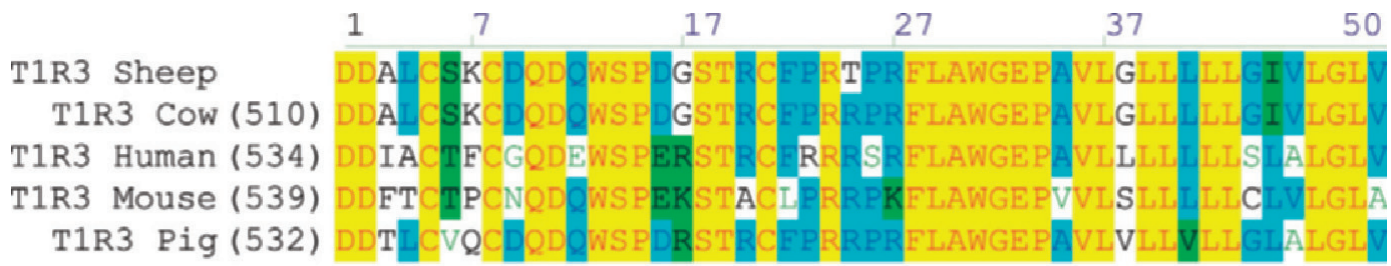

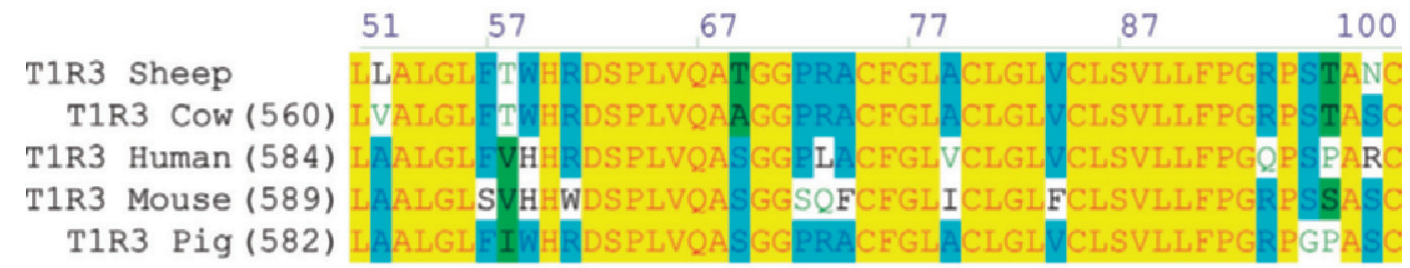

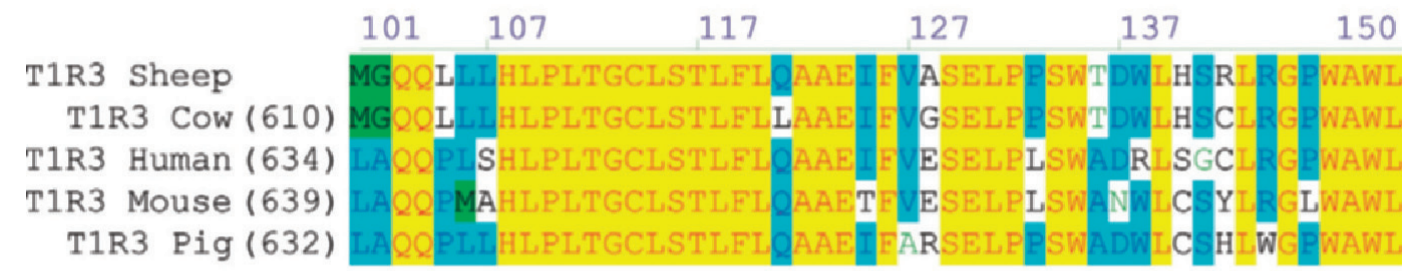

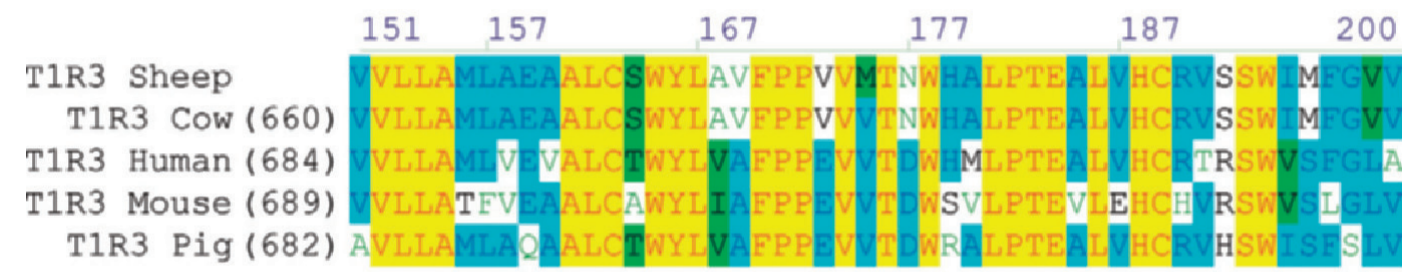

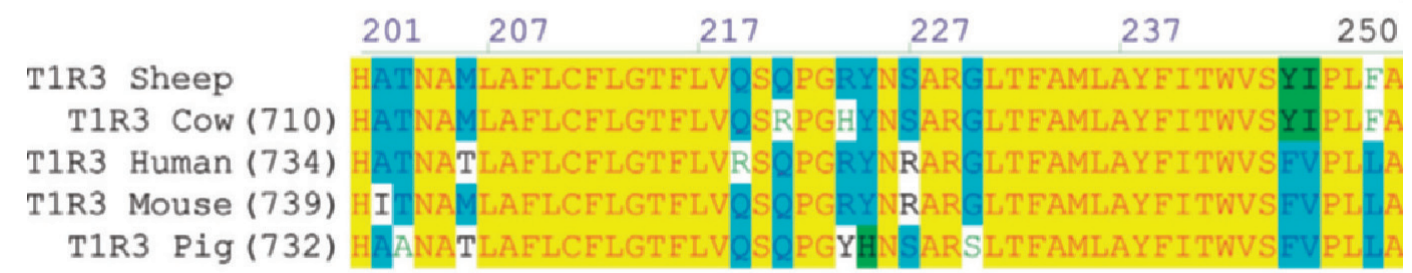

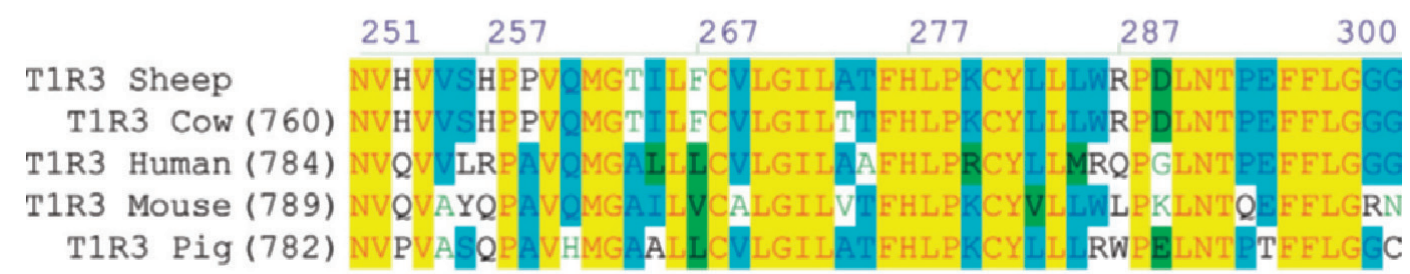

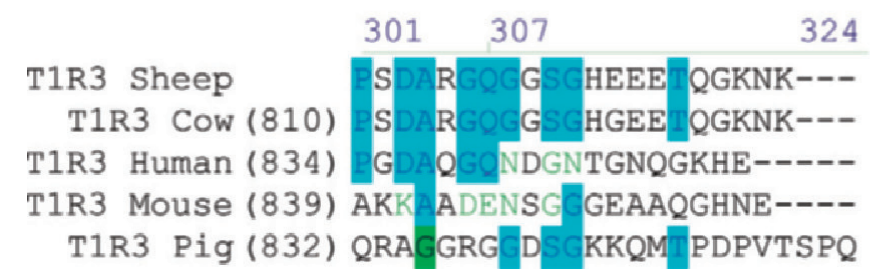

Figure 2. Alignment of ovine taste 1 receptor 3 (T1R3) AA sequence (321 AA fragments deduced from the cloned mRNA nucleotide sequence) with the corresponding region of cow, pig, human, and mouse T1R3 (numbers in parentheses relate to initiating Met residue). Color version available in the online PDF. 

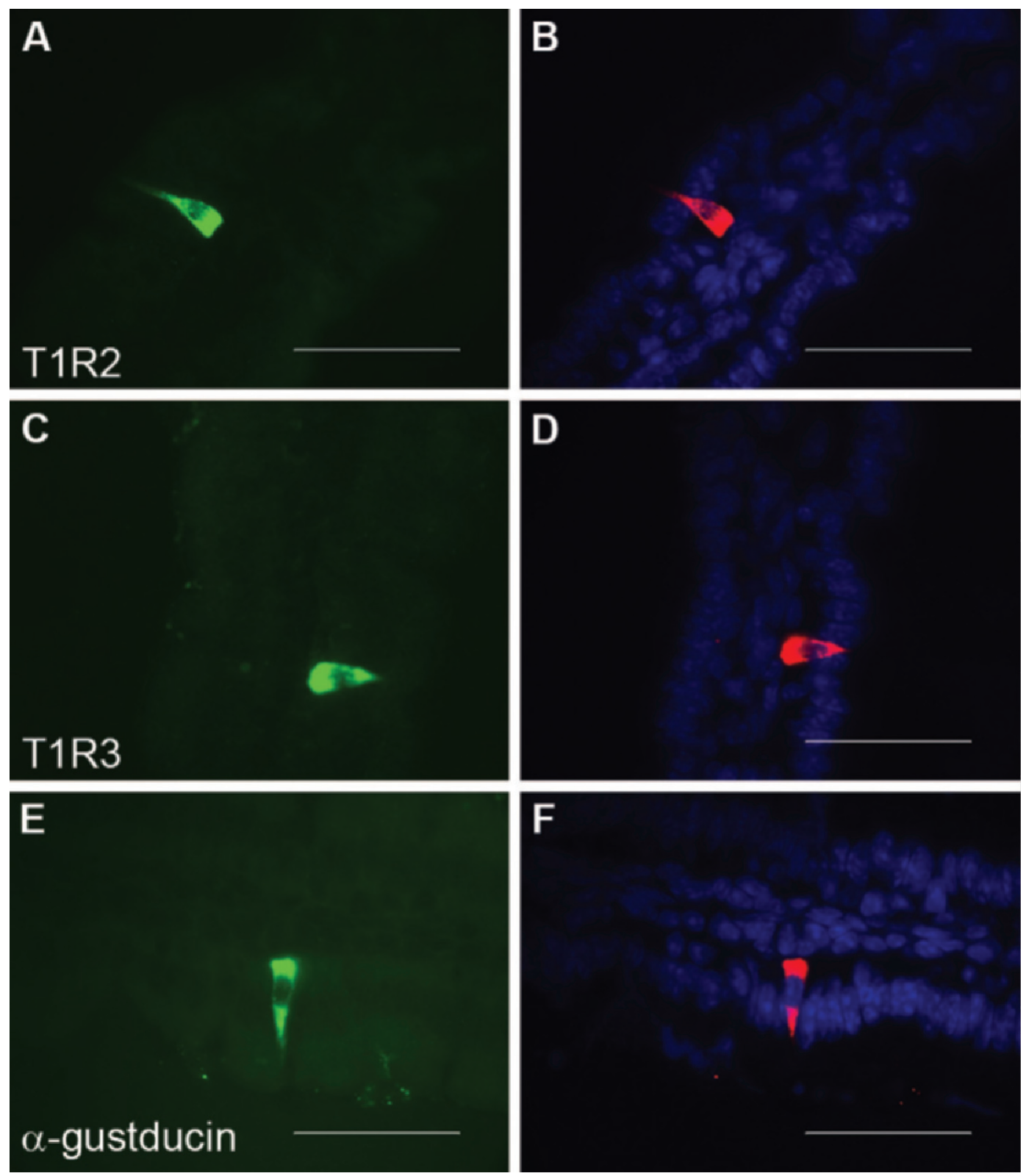

Figure 3. A representative figure showing immunohistochemical localization of taste 1 receptor 2 (T1R2), taste 1 receptor 3 (T1R3), and Q-gustducin in the ovine small intestine. Sections of ovine jejuna were probed with fluorescently labeled antibodies to T1R2 (A and B), T1R3 $(\mathrm{C}$ and $\mathrm{D})$, and $\alpha$-gustducin (E and F). In figures B, D, and F, nuclei are stained with 4',6-diaminido-2-phenylindole (darker gray/blue); images shown at $1,000 \times$ magnification; scale bar $=10 \mu \mathrm{m}$. Color version available in the online PDF.

expressing T1R2 and T1R3 also possess GLP-2, supporting their functional association.

\section{Expression of SGLT1 in Ruminant Calf Intestine is Upregulated by Supplementation of Feed with Sucram}

Fifty-day-old calves maintained on a milk-replacer diet supplemented with Sucram (SUC 1), tended to express $(P<0.10)$ higher intestinal SGLT1 mRNA abundance (Figure 5A), but no change was detected ( $P$ $=0.60)$ in the initial rate of $\mathrm{Na}^{+}$-dependent D-glucose uptake in BBMV isolated from their intestines compared to control calves maintained on milk replacer alone (Con 1; Figure 5B). Initial rates of $\mathrm{Na}^{+}$-dependent glucose uptake were $83 \pm 27.5$ and $132.5 \pm 79 \mathrm{pmol} / \mathrm{s}$ per milligram of protein, respectively, showing wide interindividual variation.

In 110-d-old ruminant calves maintained for $60 \mathrm{~d}$ on a starter concentrate diet containing Sucram (SUC 2), 
A
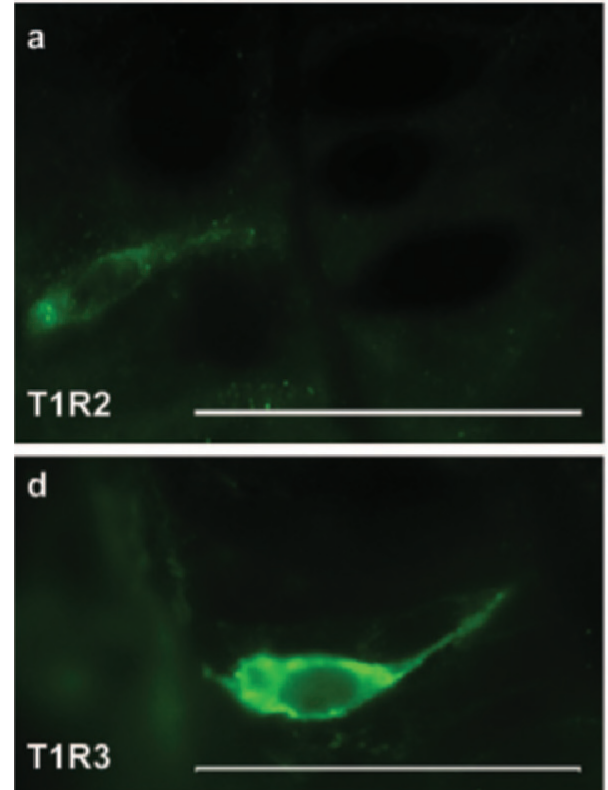

g

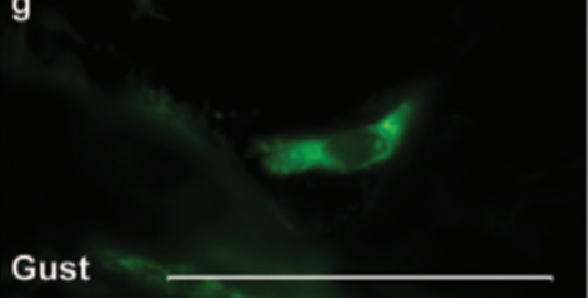

\section{b}

\section{ChA}

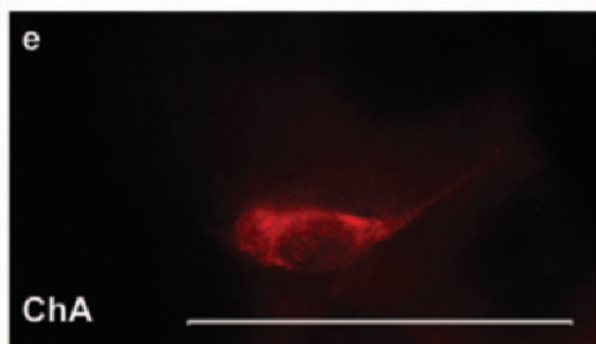

h

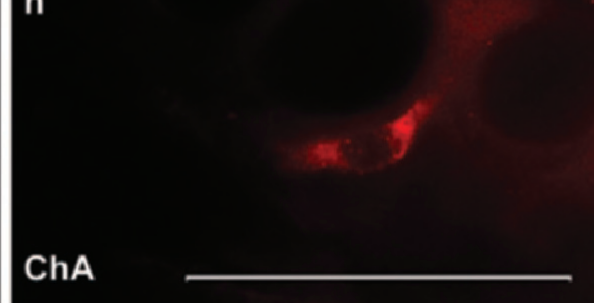

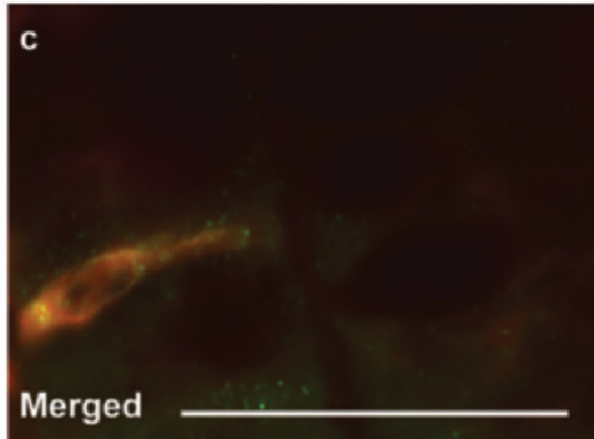

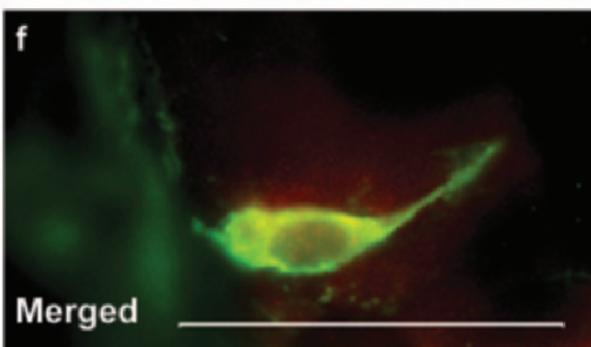

i

Merged
B

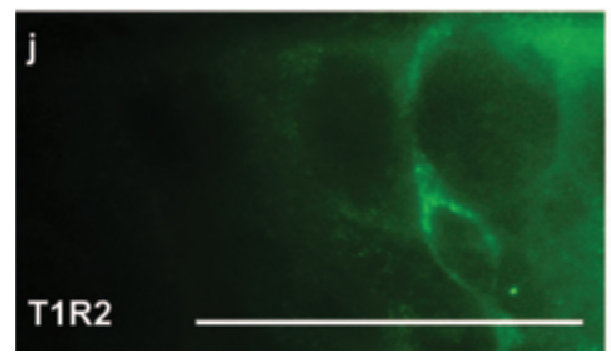

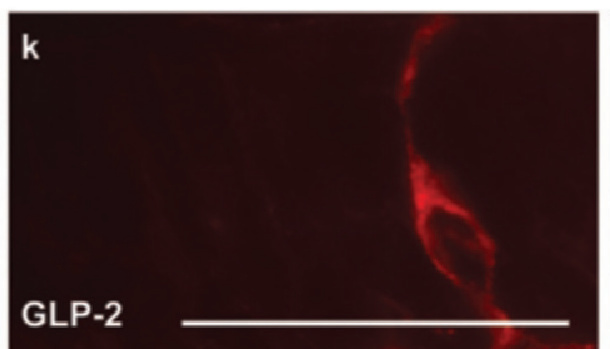

Figure 4. A representative image demonstrating that bovine L-enteroendocrine cell expresses taste 1 receptor 2 (T1R2), taste 1 receptor 3 (T1R3), and $\alpha$-gustducin. (A) Sections of bovine duodenal tissues were probed with antibodies to T1R2 (a), T1R3 (d), $\alpha$-gustducin (Gust; g), and chromogranin A (ChA; b, e, and h). Merged images (c, f, and i) demonstrate co-expression. (B) Co-localization (l) of T1R2 (j) and glucagonlike peptide-2 (GLP-2; k) shows that T1R2 is present in L-enteroendocrine cells expressing GLP-2. A similar co-expression pattern was obtained for T1R3 and GLP-2. Images shown at 1,000× magnification; scale bar $=10 \mu \mathrm{m}$.

SGLT1 mRNA abundance was similar $(P=0.55)$ to controls (Con 2; Figure 5A). However, rates of $\mathrm{Na}^{+}-$ dependent D-glucose uptake into BBMV isolated from the intestines were $105 \pm 15$ (SUC 2) and $31 \pm 17.6$ (Con 2), demonstrating a 3.4-fold $(P=0.03)$ increase in SGLT1 function in the Sucram-fed 110-d-old calves (Figure 5B). In a separate study, when adult cows were fed either a control diet or the same diet containing Sucram for $5 \mathrm{~d}$, SGLT1 protein abundance in BBMV isolated from the intestine of the Sucram-fed group was 7.3-fold $(P=0.002)$ higher than that measured in the control group, demonstrating a significant enhancement of SGLT1 abundance in response to Sucram (Figure 6). We have shown consistently that a good quantitative 
correlation exists between SGLT1 protein abundance and function (Shirazi-Beechey et al., 1991; Wood et al., 2000; Dyer et al., 2003).

\section{Changes in Villus Height and Crypt Depth in Calves in Response to Supplementation of Feed with Sucram}

Morphometric analyses demonstrated that no differences existed between the villus height $(P=0.24)$ and crypt depth $(P=0.89)$ in the duodenum of 50-d-old milk-fed calves (Con 1) or those supplemented with Sucram (SUC 1; Figure 7). However, in response to inclusion of Sucram in the diet of 110-d-old ruminating calves (SUC 2$)$, 1.4- $(P=0.0012)$ and 1.2 -fold $(P$ $=0.038)$ increases in villus height and crypt depth, respectively, were observed (Figure 7). The values for mean villus height for Con 2 and SUC 2 were $219 \pm 10$ and $308 \pm 8.5 \mu \mathrm{m}$, respectively, with mean crypt depth being $118 \pm 9$ and $140 \pm 3 \mu \mathrm{m}$, respectively.

\section{Maltase and Alkaline Phosphatase-Specific Activity in BBMV Isolated from the Calf Intestine}

Specific activities of maltase and alkaline phosphatase were similar in BBMV isolated from the intestine of 50-d-old milk-fed calves (Con 1) or those supplemented with Sucram (SUC 1; Figure 8). In contrast, in BBMV isolated from the intestine of 110-d-old ruminating calves supplemented with Sucram (SUC2), compared to controls (CON2), 1.5-fold increases were noted in both maltase- $(P=0.03)$ and alkaline phosphatasespecific $(P=0.04)$ activities (Figure 8$)$. Mean specific activity for Con 2 and SUC 2 were $16 \pm 2.7$ and 24 $\pm 1.5 \mathrm{nmol} / \mathrm{min}$ per milligram of protein for maltase, and $163 \pm 6$ and $249 \pm 37 \mathrm{nmol} / \mathrm{min}$ per milligram of protein for alkaline phosphatase, respectively.

\section{Exposure of the Ruminant Intestine to Glucose or Artificial Sweeteners Evokes GLP-2 Release}

Due to the ease of availability of fresh sheep intestinal tissues, sheep intestinal explants were used in this study. Figure 9 shows that exposure of sheep proximal intestinal explants to $300 \mathrm{~m} M$ glucose or $5 \mathrm{~m} M$ artificial sweetener (sucralose, saccharin, or NHDC) evokes GLP2 secretion. We determined, using a range of glucose concentrations, that $300 \mathrm{~m} M$ glucose evokes maximal GLP-2 release from tissue explants (data not shown), and that this secretion is not due to the effect of media osmolarity; $300 \mathrm{~m} M$ mannitol did not elicit GLP-2 secretion (Figure 9). Incubation of ovine intestinal tissue explants with $300 \mathrm{~m} M$ D-glucose resulted in a 1.6-fold increase $(P<0.01)$ in secretion of GLP-2 compared to untreated control tissues or tissues exposed to $300 \mathrm{mM}$ mannitol. Furthermore, the artificial sweeteners, sucralose, saccharin, and NHDC, evoked 1.8- $(P<0.001)$, 1.8 - $(P<0.001)$, and 1.7 -fold $(P<0.001)$ increases in GLP-2 secretion, respectively (Figure 9).

\section{DISCUSSION}

\section{Effect of Sucram on Expression of SGLT1}

The data presented in the current paper suggest that inclusion of Sucram in the feed of ruminant animals significantly enhances intestinal SGLT1 expression, as has previously been demonstrated in rodents (Margolskee et al., 2007; Stearns et al., 2010) and pigs (Moran et al., 2010a). This will provide a higher intestinal capacity to absorb glucose. However, the increase in SGLT1 expression in the intestine of milk-fed calves in response to Sucram supplementation was not statistically significant, mainly due to high interanimal variation and low animal numbers. Further studies are required to assess if Sucram does indeed have any significant effect on SGLT1 expression in the preruminant intestine. However, it may be also rationalized that the intestine of preruminants already possesses high levels of basal SGLT1 expression, sufficient for absorbing glucose released from the milk sugar lactose.

Sucram contains both saccharin and NHDC, and the question arises as to which of these sweeteners may be sensed by the intestinal sweet receptor, leading to changes in SGLT1 expression. Using explants of sheep intestine, we demonstrated that exposure of the tissue to sucralose, saccharin, or NHDC results in secretion of GLP-2, the gut hormone known to enhance SGLT1 expression (Cheeseman, 1997). It is well established that these sweeteners are detected by the sweet receptor through binding to specific AA residues on T1R2 and T1R3, evoking downstream signaling (Winnig et al., 2005; Assadi-Porter et al., 2010). However, in vivo, these sweeteners have to pass through the rumen, which possesses vast numbers of microbiota capable of metabolizing a huge variety of compounds.

Saccharin has previously been shown to be resistant to degradation by intestinal microbiota (Lethco and Wallace, 1975; Buerge et al., 2011). We have also demonstrated, using HPLC, that the concentration and quantity of saccharin remain constant during transit through the gastrointestinal tract (K. Daly, University of Liverpool, Liverpool, UK, and S. P. Shirazi-Beechey; unpublished data). The NHDC is a flavonoid glycoside that is neither absorbed nor metabolized by the host tissue (Braune at al., 2005). It has, however, been shown that NHDC can be degraded and metabolized by the combined action of a number of bacterial groups 
A

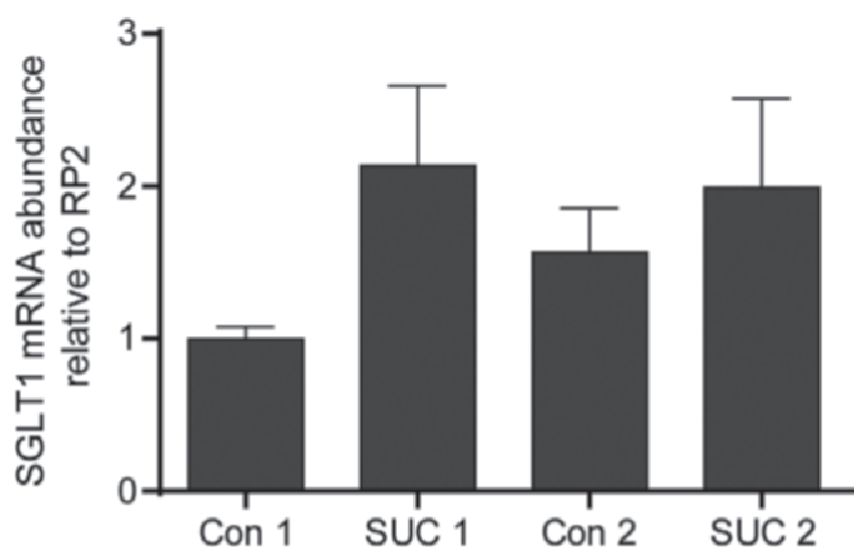

B

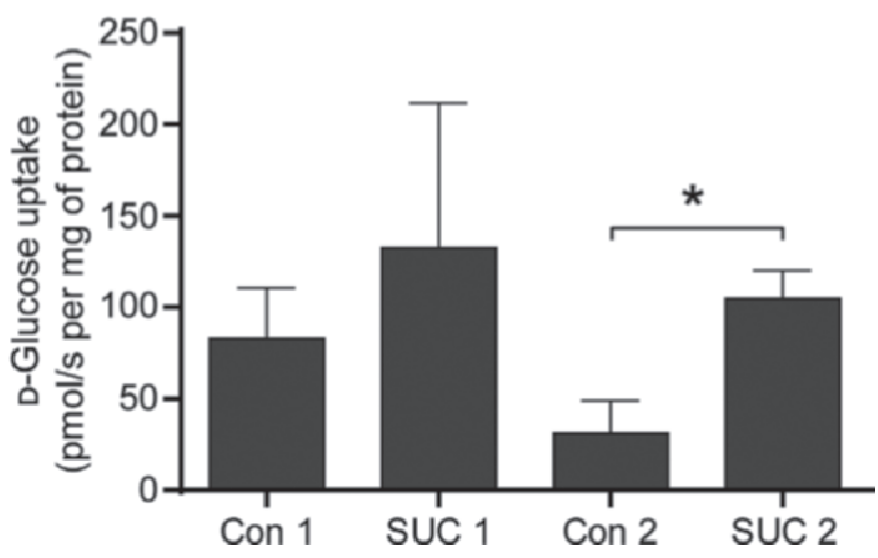

Figure 5. Expression of sodium-glucose co-transporter 1 (SGLT1) mRNA and protein function in bovine intestine in response to supplementation of feed with the artificial sweetener Sucram (saccharin and neohesperidin dihydrochalcone). Brush border membrane vesicles (BBMV) and RNA were isolated from duodenal tissues of calves maintained for $50 \mathrm{~d}$ on a milk-replacer $\operatorname{diet}(\mathrm{Con} 1, \mathrm{n}=4$, group 1 ) or supplemented with Sucram (SUC 1, n =4, group 2), with two other groups switched for a further $60 \mathrm{~d}$ to a starter concentrate (Con 2, $\mathrm{n}=4$, group 3 ) or the same dietary regimen but supplemented with Sucram (SUC 2, $\mathrm{n}=4$, group 4). (A) Steady-state levels of SGLT1 mRNA abundance normalized to RNA polymerase II (RP2). (B) Initial rates of $\mathrm{Na}^{+}$-dependent $\left[\mathrm{U}^{14} \mathrm{C}\right]$-D-glucose uptake into BBMV. Data were generated in triplicate. Results are shown as mean \pm SEM; statistically significant results were determined using a one-way ANOVA and Dunnett's multiple comparison post-test, where an asterisk $\left(^{*}\right)$ indicates $P<0.05$.

(Braune at al., 2005). From these observations it was concluded that, in vivo, saccharin is the sweetener detected by the ruminant intestinal T1R2-T1R3 receptor, leading to SGLT1 upregulation.

In these studies, due to the complexity of the technique and not having animals with cannulation of the hepatic portal vein at hand, we were not able to measure blood glucose concentrations to demonstrate that enhanced expression of SGLT1 results in increased
A
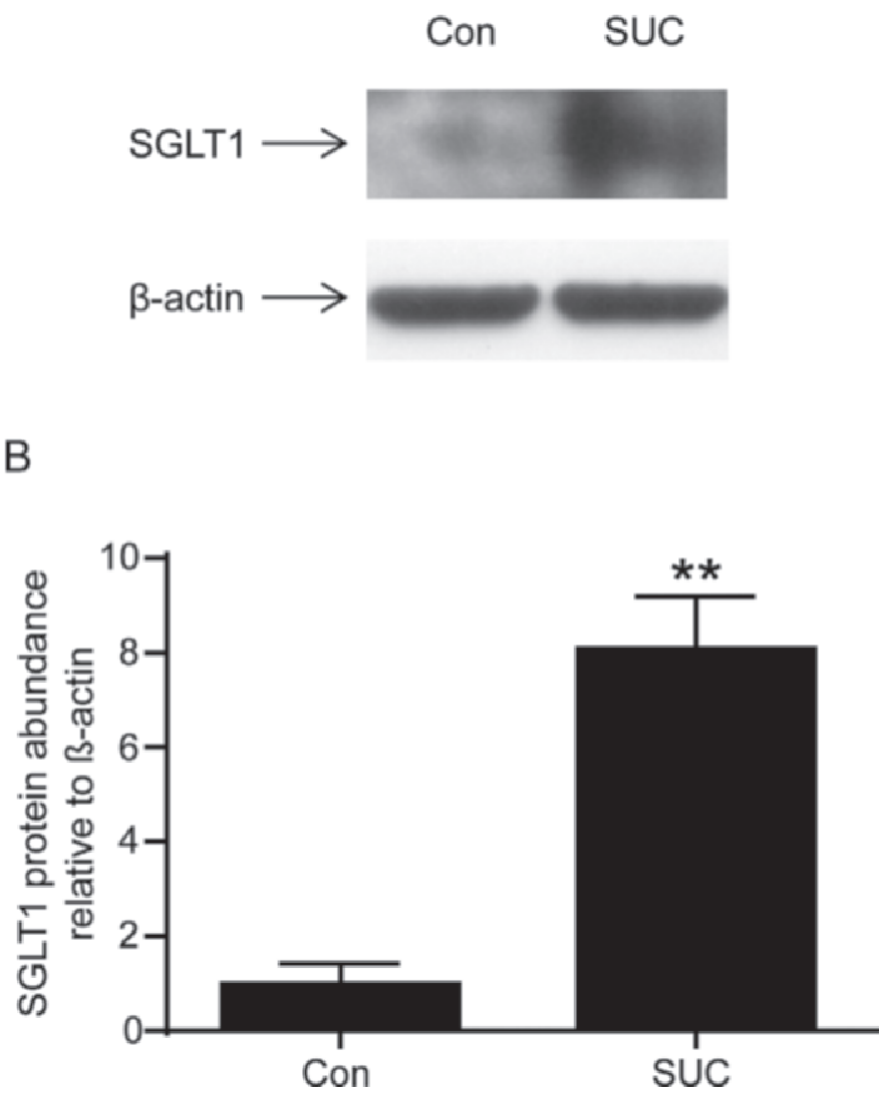

Figure 6. Expression of sodium-glucose co-transporter 1 (SGLT1) protein in the bovine intestine in response to feed supplementation with the artificial sweetener Sucram (saccharin and neohesperidin dihydrochalcone). Two groups of cows in the dry period, 45 to $60 \mathrm{~d}$ before parturition, were fed either a control $(\mathrm{Con}, \mathrm{n}=2)$ diet or the same diet supplemented with Sucram (SUC, $n=4)$. (A) Expression of SGLT1 and $\beta$-actin proteins in brush border membrane vesicles isolated from duodenal biopsies assessed by Western blotting. (B) Densitometric analysis of Western blots normalized SGLT1 protein abundance to $\beta$-actin. Results are expressed as mean \pm SEM; statistically significant results were determined using a one-way ANOVA and Dunnett's multiple comparison post-test, where two asterisks $(* *)$ indicates $P<0.01$.

concentration of blood glucose. Interestingly, our data indicate that when 110-d-old ruminating calves were maintained on a starch-based diet for $60 \mathrm{~d}$, rates of $\mathrm{Na}^{+}$-dependent glucose uptake in BBMV isolated from the intestine $(31 \pm 17 \mathrm{pmol} / \mathrm{s}$ per milligram of protein), were several orders of magnitude higher than rates reported in BBMV isolated from the intestine of ruminant cows kept on conventional roughage diets $(0.5 \pm$ $0.2 \mathrm{pmol} / \mathrm{s}$ per milligram of protein; Wood et al., 2000). The present study suggests that these calves either had higher SGLT1 expression levels or that starch escaping the rumen had been hydrolyzed to glucose, as the expression of SGLT1 is upregulated by glucose and not by starch (Shirazi-Beechey et al., 1991; Wood, 1995; 
A

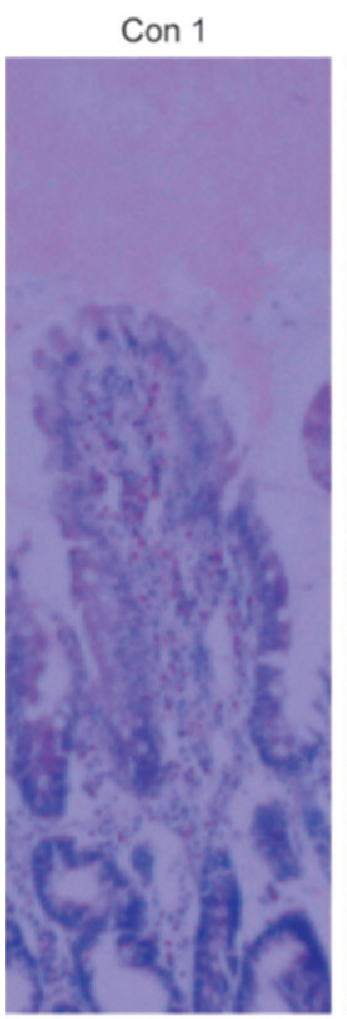

SUC 1

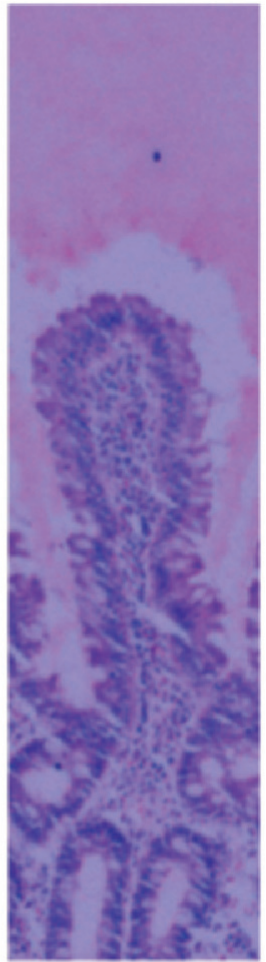

Con 2

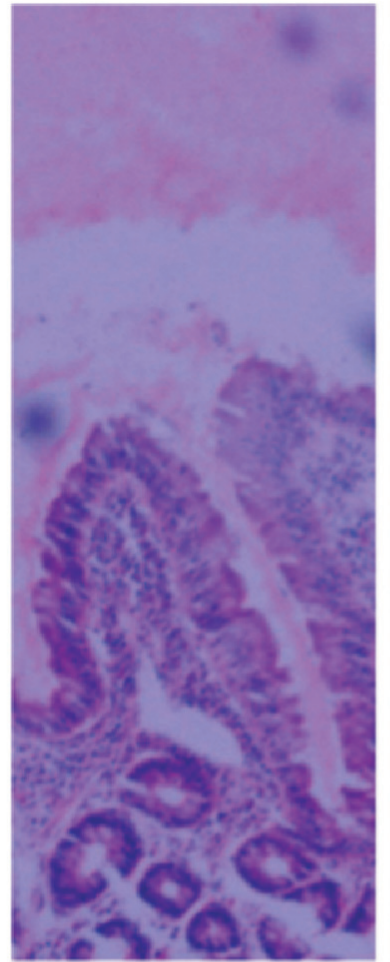

SUC 2

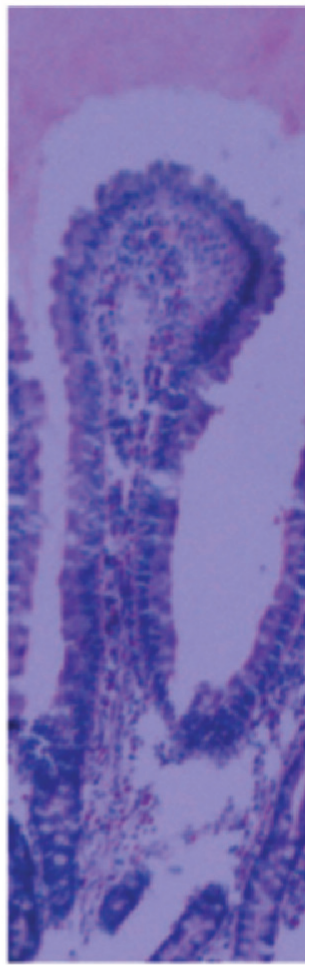

B

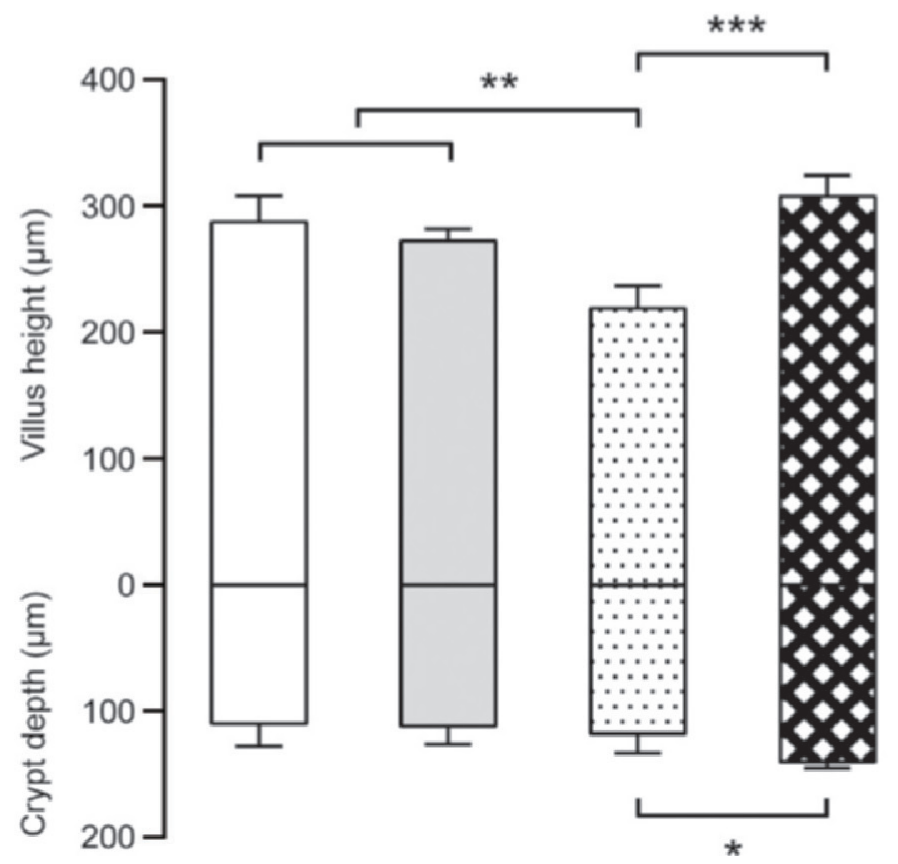

Figure 7. Villus height and crypt depth increase in the duodenum of ruminating calves in response to supplementation with the artificial sweetener Sucram (saccharin and neohesperidin dihydrochalcone). (A) Representative light micrographs of duodenal tissues of 50-d-old milk-fed calves (Con 1), 50-d-old milk-fed calves with Sucram supplementation (SUC 1), 110-d-old ruminating calves (Con 2), and 110-d-old ruminating calves with Sucram supplementation (SUC 2). Images were obtained at 40× magnification. (B) Morphometric analyses of villus height and crypt depths are shown as histograms ( $\mu \mathrm{m} \pm \mathrm{SEM}$ ): Con 1 (white bar), SUC 1 (gray bar), Con 2 (dotted bar), SUC 2 (checked bar); $\mathrm{n}=3$ to 4 animals. Statistically significant results were determined using one-way ANOVA with Dunnett's post-test. An asterisk $(*)$ indicates $P<0.05$; 2 asterisks $\left({ }^{*}\right)$ indicates $P<0.01 ; 3$ asterisks $(* * *)$ indicates $P<0.001$. Color version available in the online PDF. 
A

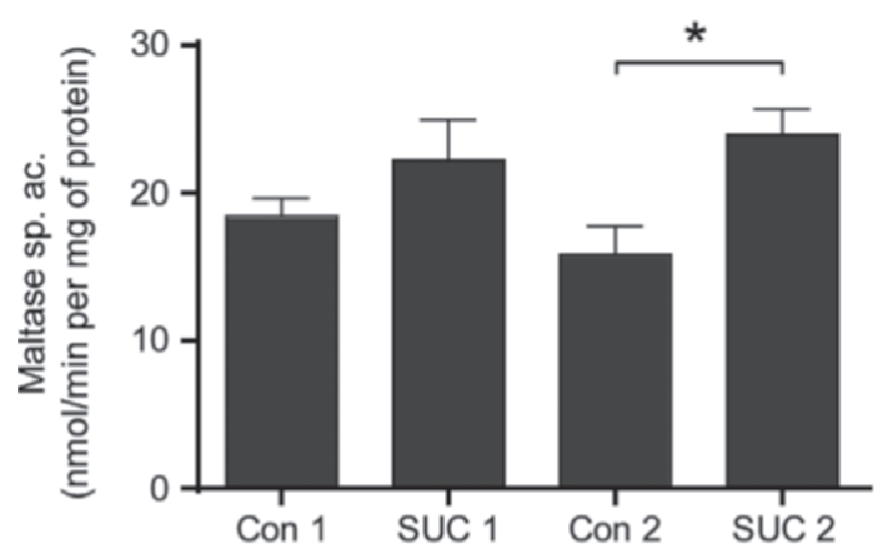

B

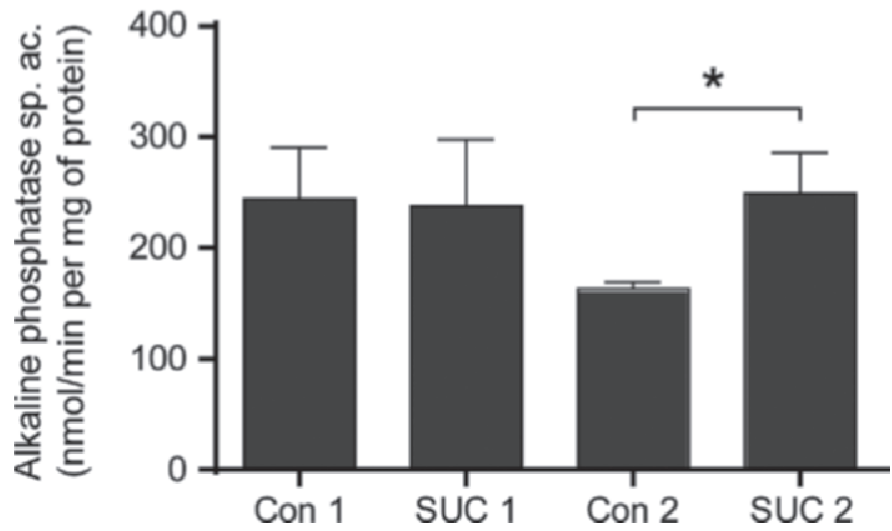

Figure 8. Changes in specific activities of maltase and alkaline phosphatase in the bovine intestine in response to supplementation with the artificial sweetener Sucram (saccharin and neohesperidin dihydrochalcone). Brush border membrane vesicles (BBMV) were isolated from duodenal tissues of calves maintained for $50 \mathrm{~d}$ on a milkreplacer diet (Con 1, $\mathrm{n}=4$, group 1) or supplemented with Sucram (SUC 1, n $=4$, group 2), with 2 other groups switched to a starter concentrate for further $60 \mathrm{~d}$ (Con $2, \mathrm{n}=4$, group 3) or the same dietary regimen but supplemented with Sucram (SUC 2, n $=4$, group 4). Maltase- (A) and alkaline phosphatase-specific (B) activities were measured in BBMV. Data were generated in triplicate. Results are shown as mean specific activity (nmol/min per milligram of protein) \pm SEM; statistically significant results were determined using a one-way ANOVA and Dunnett's multiple comparison post-test. An asterisk $\left(^{*}\right)$ indicates $P<0.05$.

Dyer et al., 2003). Moreover, the disparity between Sucram-induced increases in SGLT1 mRNA abundance and glucose transport protein function in the intestine of ruminating calves indicates that the regulation of SGLT1 expression is at post-transcriptional levels, as shown previously in ovine intestine (Freeman et al., 1993; Lescale-Matys et al., 1993; Wood et al., 2000).

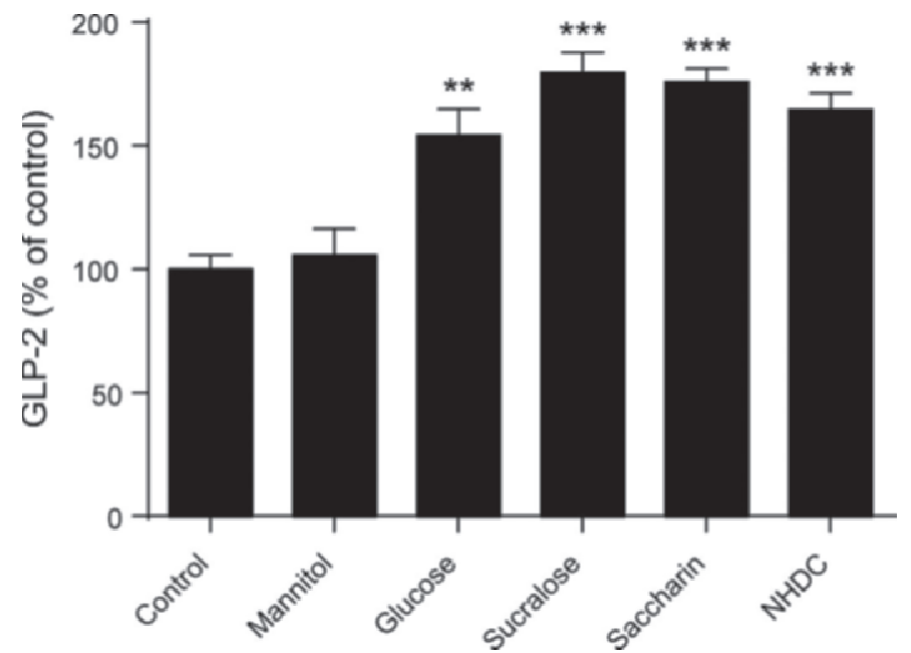

Figure 9. Effects of glucose, mannitol, sucralose, saccharin, and neohesperidin dihydrochalcone (NHDC) on glucagon-like peptide-2 (GLP-2) secretion from the sheep intestine. Sheep jejunal tissues were cut into $\sim 2$-cm sheets with the serosa removed, as previously described (Daly et al., 2012), and incubated in $500 \mu \mathrm{L}$ of media consisting of low-glucose (5.55 mM) Dulbecco's modified Eagle's medium (DMEM) supplemented with $10 \%$ (vol/vol) fetal bovine serum, 100 units $/ \mathrm{mL}$ of penicillin, $100 \mu \mathrm{g} / \mathrm{mL}$ of streptomycin, and $20 \mu \mathrm{L} / \mathrm{mL}$ of dipeptidyl peptidase- 4 inhibitor, gassed with carbogen $\left(5 \% \mathrm{CO}_{2}, 95 \% \mathrm{O}_{2}\right)$, and supplemented with either $300 \mathrm{~m} M$ glucose, $300 \mathrm{mM}$ mannitol, or 5 $\mathrm{m} M$ sucralose, saccharin, or $\mathrm{NHDC}$ for $1 \mathrm{~h}$ at $37^{\circ} \mathrm{C}, 5 \% \mathrm{CO}_{2}$. The GLP-2 content of media was measured as described $(n=4)$. Results are expressed as mean $+\mathrm{SEM}$, where $P$-values are based on one-way ANOVA with Bonferroni's multiple comparison post-test; 2 asterisks $(* *)$ indicates $P<0.01$ and 3 asterisks $(* * *)$ indicates $P<0.001$.

\section{Mechanism Underlying Sweetener-Induced SGLT1 Upregulation; Identification of Molecular Targets}

It is known that in response to dietary monosaccharides L-endocrine cells secrete GLP-1 and GLP-2 (Rehfeld, 2004). It was previously thought that L-cells were present mainly in the distal intestine. However, more recent research has demonstrated that, in addition to colon and ileum, duodenum and jejunum also contain L-cells (Theodorakis et al., 2006; Steinert et al., 2011; Daly et al., 2013). Both GLP-1 and GLP-2 are products of the pro-glucagon gene $(G C G$; Orskov et al., 1987) and are both co-secreted from L-cells. They have a very short circulating half-life, due to their degradation by the enzyme DPPIV (Hartmann et al., 2000). The GLP-1 increases insulin secretion, whereas GLP-2 has a tropic effect enhancing intestinal mucosal growth (Tsai et al., 1997, Ramsanahie et al., 2003; Cottrell et al., 2006). In pigs and rodents, GLP-2 stimulation of intestinal growth is evident by increased villus height (i.e. increased number of villus cells) and crypt depth (Burrin et al., 2000; Hartmann et al., 2000; Ramsanahie et al., 2003). Additionally, GLP-2 increases expression of SGLT1 protein molecules in the intestinal brush border membrane (Cheeseman, 1997; Ramsanahie et 
al., 2003; Cottrell et al., 2006). The latter observation was supported by detailed studies of Cheeseman (1997), demonstrating that in vivo vascular infusion of GLP-2 in rats increases, with similar magnitudes, the maximal rates of $\mathrm{Na}^{+}$-dependent glucose transport and $\mathrm{Na}^{+}$-dependent phlorizin binding, as well as increasing SGLT1 protein abundance in the intestinal brush border membrane. Furthermore, this GLP-2 effect is inhibited by brefeldin A, an inhibitor of protein translocation from the trans-Golgi apparatus to the plasma membrane (Hunziker et al., 1991; Helms and Rothman, 1992).

We have shown previously that exposure of mouse small intestinal tissue to glucose and artificial sweeteners evokes release of GLP-2, and that this secretion is inhibited by gurmarin (Daly et al., 2012), an inhibitor of the murine sweet taste receptor (Ninomiya and Imoto, 1995; Maillet et al., 2009), supporting the conclusion that glucose- or sweetener-induced GLP-2 release occurs through the activation of gut-expressed T1R2T1R3. In the current paper, we have demonstrated that the intestines of sheep and cow, similar to nonruminant species, express T1R2, T1R3, and gustducin, and that these sweet-signaling molecules are expressed in GLP-2 containing L-cells, showing their functional association. Furthermore, exposure of the sheep small intestine to glucose and to the artificial sweeteners, sucralose, saccharin, and NHDC, evokes secretion of GLP-2. Notably, supplementation of the diet of ruminating calves with Sucram led to significant increases in villus height (1.4-fold) and brush border membrane enzyme (alkaline phosphatase and maltase; 1.5-fold) compared to controls. Close similarities exist between the magnitude of increases in specific activities of maltase and alkaline phosphatase, markers of villus differentiated cells, and villus height. The data support the conclusion that the intestinotropic peptide, GLP-2, secreted in response to Sucram supplementation, increases the number of villus differentiated cells. However, the disparity between the observed increases in $\mathrm{Na}^{+}$-dependent D-glucose uptake (3.4-fold), and villus height or enzyme activities (1.4/1.5-fold), indicates that sweetener-induced SGLT1 upregulation is only partly due to increased villus cell number, but also owed to enhancement in the number of SGLT1 proteins per enterocyte.

Collectively, these studies suggest that dietary supplements, such as artificial sweeteners, that induce GLP2 release, can be used to enhance intestinal growth, maturity, and glucose absorption. This has applications for maintaining health and productivity of domestic animals.

It has been predicted that global consumption of meat will increase from 209 million tonnes in 1997 to 334 million tonnes in 2020. Similarly, global production of milk is projected to increase from 445 to 661 million $\mathrm{t}$ in the same period (Delgado, 2003). Increased price variability in starch-containing raw materials (e.g. corn) is beginning to discourage the use of such ingredients in animal feed production. With this in mind, it can be predicted that ruminants may progressively lose out in competition for starch with humans, nonruminant livestock, and biofuels.

With the population of the world increasing at ever more alarming rates, it is envisaged that domestic animals may be almost completely dependent upon rangeland forages or agricultural and industrial wastes for their nutritional sustenance. Therefore, understanding the molecular characteristics of the digestive physiology and the sensory component of the food acceptance process, and how they can be modified by certain naturally occurring compounds, becomes increasingly important. As such, there will be plenty of interesting and challenging research opportunities to entertain animal scientists and nutritionist for years to come.

\section{ACKNOWLEDGMENTS}

We acknowledge the financial support of Pancosma SA. S. P. Shirazi-Beechey is grateful to John Newbold (Cargill Animal Nutrition, Velddriel, the Netherlands) for fruitful discussions. C. Zhang was funded by a prestigious scholarship provided by Jiangsu Overseas Research Training Program (Jiangsu, China), and National Natural Science Foundation of China (Beijing, China; grant no. 31101703) to work in S. P. ShiraziBeechey's laboratory. M. Al-Rammahi was supported by a doctoral fellowship awarded by the Iraqi Ministry of Higher Education and Scientific Research (Baghdad, Iraq) to study in S. P. Shirazi-Beechey's laboratory.

\section{REFERENCES}

Assadi-Porter, F. M., E. L. Maillet, J. T. Radek, J. Quijada, J. L. Markley, and M. Max. 2010. Key amino acid residues involved in multi-point binding interactions between brazzein, a sweet protein, and the T1R2-T1R3 human sweet receptor. J. Mol. Biol. 398:584-599.

Batchelor, D. J., M. Al-Rammahi, A. W. Moran, J. G. Brand, X. Li, M. Haskins, A. J. German, and S. P. Shirazi-Beechey. 2011. Intestinal sodium/glucose cotransporter-1 (SGLT1) and disaccharidase expression in the domestic dog and cat: Two species of different dietary habit. Am. J. Physiol. Regul. Integr. Comp. Physiol 300:R67-R75.

Braune, A., W. Engst, and M. Blaut. 2005. Degradation of neohesperidin dihydrochalcone by human intestinal bacteria. J. Agric. Food Chem. 53:1782-1790.

Buerge, I. J., M. Keller, H. R. Buser, M. D. Müller, and T. Poiger 2011. Saccharin and other artificial sweeteners in soils: Estimated inputs from agriculture and households, degradation, and leaching to groundwater. Environ. Sci. Technol. 45:615-621.

Burrin, D. G., B. Stoll, R. Jiang, Y. Petersen, J. Elnif, R. K. Buddington, M. Schmidt, J. J. Holst, B. Hartmann, and P. T. Sangild. 2000. GLP-2 stimulates intestinal growth in premature TPN-fed 
pigs by suppressing proteolysis and apoptosis. Am. J. Physiol. Gastrointest. Liver Physiol. 279:G1249-G1256.

Cheeseman, C. I. 1997. Upregulation of SGLT-1 transport activity in rat jejunum induced by GLP-2 infusion in vivo. Am. J. Physiol. 273:R1965-R1971

Cottrell, J. J., B. Stoll, R. K. Buddington, J. E. Stephens, L. Cui, X. Chang, and D. G. Burrin. 2006. Glucagon-like peptide-2 protects against TPN-induced intestinal hexose malabsorption in enterally refed piglets. Am. J. Physiol. Gastrointest. Liver Physiol. 290:G293-G300.

Dahlqvist, A. 1964. Method for assay of intestinal disaccharidases. Anal. Biochem. 7:18-25.

Daly, K., M. Al-Rammahi, D. K. Arora, A. W. Moran, C. J. Proudman, Y. Ninomiya, and S. P. Shirazi-Beechey. 2012. Expression of sweet receptor components in equine small intestine: Relevance to intestinal glucose transport. Am. J. Physiol. Regul. Integr. Comp. Physiol. 303:R199-R208.

Daly, K., M. Al-Rammahi, A. W. Moran, M. Marcello, Y. Ninomiya, and S. P. Shirazi-Beechey. 2013. Sensing of amino acids by the gutexpressed taste receptor, T1R1-T1R3, stimulates CCK secretion. Am. J. Physiol. Gastrointest. Liver Physiol. 304:G271-G282.

Delgado, C. L. 2003. Rising consumption of meat and milk in developing countries has created a new food revolution. J. Nutr. 133(Suppl. 2):3907S-3910S.

Drucker, D. J., P. Erlich, S. L. Asa, and P. L. Brubaker. 1996. Induction of intestinal epithelial proliferation by glucagon-like peptide 2 . Proc. Natl. Acad. Sci. USA 93:7911-7916.

Dyer, J., M. Al-Rammahi, L. Waterfall, K. S. Salmon, R. J. Geor, L. Bouré, G. B. Edwards, C. J. Proudman, and S. P. Shirazi-Beechey. 2009. Adaptive response of equine intestinal $\mathrm{Na}^{+} /$glucose co-transporter (SGLT1) to an increase in dietary soluble carbohydrate. Pflugers Arch. 458:419-430.

Dyer, J., K. S. Salmon, L. Zibrik, and S. P. Shirazi-Beechey. 2005. Expression of sweet taste receptors of the T1R family in the intestinal tract and enteroendocrine cells. Biochem. Soc. Trans. 33:302-305.

Dyer, J., S. Vayro, T. P. King, and S. P. Shirazi-Beechey. 2003. Glucose sensing in the intestinal epithelium. Eur. J. Biochem. 270:3377-3388.

Firkins, J. L., M. L. Eastridge, N. R. St-Pierre, and S. M. Noftsger. 2001. Effects of grain variability and processing on starch utilization by lactating dairy cows. J. Anim. Sci. 79:E218-E238.

Freeman, T. C., I. S. Wood, D. J. Sirinathsinghji, R. B. Beechey, J. Dyer, and S. P. Shirazi-Beechey. 1993. The expression of the $\mathrm{Na}^{+} /$ glucose cotransporter (SGLT1) gene in lamb small intestine during postnatal development. Biochim. Biophys. Acta 1146:203-212.

Harmon, D. L. 2009. Understanding starch utilization in the small intestine of cattle. Asian-australas. J. Anim. Sci. 22:915-922.

Hartmann, B., M. B. Harr, P. B. Jeppesen, M. Wojdemann, C. F Deacon, P. B. Mortensen, and J. J. Holst. 2000. In vivo and in vitro degradation of glucagon-like peptide-2 in humans. J. Clin. Endocrinol. Metab. 85:2884-2888.

Helms, J. B., and J. E. Rothman. 1992. Inhibition of brefeldin A of a Golgi membrane enzyme that catalyses exchange of guanine nucleotide bound to ARF. Nature 360:352-354.

Hunziker, W., J. A. Whitney, and I. Mellman. 1991. Selective inhibition of transcytosis in brefeldin A in MDCK cells. Cell 67:617627.

Jang, H. J., Z. Kokrashvili, M. J. Theodorakis, O. D. Carlson, B. J. Kim, J. Zhou, H. H. Kim, X. Xu, S. L. Chan, M. Juhaszova, M. Bernier, B. Mosinger, R. F. Margolskee, and J. M. Egan. 2007. Gut-expressed gustducin and taste receptors regulate secretion of glucagon-like peptide-1. Proc. Natl. Acad. Sci. USA 104:1506915074 .

Lescale-Matys, L., J. Dyer, D. Scott, T. C. Freeman, E. M. Wright, and S. P. Shirazi-Beechey. 1993. Regulation of the ovine intestinal $\mathrm{Na}+$ /glucose co-transporter (SGLT1) is dissociated from mRNA abundance. Biochem. J. 291:435-440.

Lethco, E. J., and W. C. Wallace. 1975. The metabolism of saccharin in animals. Toxicology 3:287-300.
Maillet, E. L., L. Pelletier, T. J. Cardozo, J. Quijada, P. Silie, B. Zhao, Y. Ninomiya, M. Max, and R. F. Margolskee. 2009. Gurmarin inhibits the sweet receptor by binding to the venus fly trap module of T1R3. Chem. Senses 34:A78.

Margolskee, R. F., J. Dyer, Z. Kokrashvili, K. S. Salmon, E. Ilegems, K. Daly, E. L. Maillet, Y. Ninomiya, B. Mosinger, and S. P. Shirazi-Beechey. 2007. T1R3 and gustducin in gut sense sugars to regulate expression of $\mathrm{Na}^{+}$-glucose cotransporter 1. Proc. Natl. Acad. Sci. USA 104:15075-15080.

McLaughlin, S. K., P. J. McKinnen, and R. F. Margolskee. 1992. Gustducin is a taste cell-specific G-protein closely related to transducing. Nature 357:563-569.

Moran, A. W., M. A. Al-Rammahi, D. K. Arora, D. J. Batchelor, E. A. Coulter, K. Daly, C. Ionescu, D. Bravo, and S. P. Shirazi-Beechey 2010a. Expression of $\mathrm{Na}^{+} /$glucose co-transporter 1 (SGLT1) is enhanced by supplementation of the diet of weaning piglets with artificial sweeteners. Br. J. Nutr. 104:637-646.

Moran, A. W., M. A. Al-Rammahi, D. K. Arora, D. J. Batchelor, E. A. Coulter, C. Ionescu, D. Bravo, and S. P. Shirazi-Beechey. 2010b. Expression of sodium/glucose co-transporter 1 (SGLT1) is the intestine of piglets weaned to different concentrations of dietary carbohydrate. Br. J. Nutr. 104:647-655.

NRC. 2001, Nutrient Requirements of Dairy Cattle, 7th ed. Natl. Acad. Press, Washington, DC.

Ninomiya, Y., and T. Imoto. 1995. Gurmarin inhibition of sweet taste responses in mice. Am. J. Physiol. 268:R1019-R1025.

Nocek, J. E., and S. Tamminga. 1991. Site of digestion of starch in gastrointestinal tract of dairy cows and its effect on milk yield and composition. J. Dairy Sci. 74:3598-3629.

Orskov, C., J. J. Holst, S. S. Poulsen, and P. Kirkegaard. 1987. Pancreatic and intestinal processing of proglucagon in man. Diabetologia $30: 874-881$.

Owens, F. N., R. A. Zinn, and Y. K. Kim. 1986. Limits to starch digestion in the ruminant small intestine. J. Anim. Sci. 63:1634-1648.

Ramsanahie, A., M. S. Duxbury, T. C. Grikscheit, A. Perez, D. B. Rhoads, J. Gardner-Thorpe, J. Ogilvie, S. W. Ashley, J. P. Vacanti, and E. E. Whang. 2003. Effect of GLP-2 on mucosal morphology and SGLT1 expression in tissue-engineered neointestine. Am. J. Physiol. Gastrointest. Liver Physiol. 285:G1345-G1352.

Ramsanahie, A. P., U. V. Berger, M. J. Zinner, E. E. Whang, D. B. Rhoads, and S. W. Ashley. 2004. Effect of glucagon-like peptide-2 (GLP-2) on diurnal SGLT1 expression. Dig. Dis. Sci. 49:17311737.

Rehfeld, J. F. 2004. A centenary of gastrointestinal endocrinology. Horm. Metab. Res. 36:735-741.

Rowell-Schäfer, A., J. Dyer, R. R. Hofmann, M. Lechner-Doll, H. H. D. Meyer, and S. P. Shirazi-Beechey. 1999. Abundance of intestinal $\mathrm{Na}^{+}$/glucose cotransporter (SGLT1) in roe deer (Capreolus capreolus). J. Anim. Physiol. A. Anim. Nutr. 82:25-32.

Sato, S., R. Hokari, C. Kurihara, H. Sato, K. Narimatsu, H. Hozumi, T. Ueda, M. Higashiyama, Y. Okada, C. Watanabe, S. Komoto, K. Tomita, A. Kawaguchi, S. Nagao, and S. Miura. 2013. Dietary lipids and sweeteners regulate glucagon-like peptide- 2 secretion. Am. J. Physiol. Gastrointest. Liver Physiol. 304:G708-G714.

Shirazi, S. P., R. B. Beechey, and P. J. Butterworth. 1981. The use of potent inhibitors of alkaline phosphatase to investigate the role of the enzyme in intestinal transport of inorganic phosphate. Biochem. J. 194:803-809.

Shirazi-Beechey, S. P. 1995. Molecular biology of intestinal glucose transport. Nutr. Res. Rev. 8:27-41.

Shirazi-Beechey, S. P., A. G. Davies, K. Tebbutt, J. Dyer, A. Ellis, C. J. Taylor, P. Fairclough, and R. B. Beechey. 1990. Preparation and properties of brush-border membrane vesicles from human small intestine. Gastroenterology 98:676-685.

Shirazi-Beechey, S. P., B. A. Hirayama, Y. Wang, D. Scott, M. W. Smith, and E. M. Wright. 1991. Ontogenic development of lamb intestinal sodium-glucose co-transporter is regulated by diet. J. Physiol. 437:699-708.

Shirazi-Beechey, S. P., R. B. Kemp, J. Dyer, and R. B. Beechey. 1989. Changes in the functions of the intestinal brush border membrane 
during the development of ruminant habit in lambs. Comp. Biochem. Physiol. B 94:801-806.

Shirazi-Beechey, S. P., A. W. Moran, D. J. Batchelor, K. Daly, and M. Al-Rammahi. 2011. Glucose sensing and signalling; regulation of intestinal glucose transport. Proc. Nutr. Soc. 70:185-193.

Stearns, A. T., A. Balakrishnan, D. B. Rhoads, and A. Tavakkolizadeh. 2010. Rapid upregulation of sodium-glucose transporter SGLT1 in response to intestinal sweet taste stimulation. Ann Surg. 251:865-871.

Steinert, R. E., A. C. Gerspach, H. Gutmann, L. Asarian, J. Drewe, and C. Beglinger. 2011. The functional involvement of gut-expressed sweet taste receptors in glucose-stimulated secretion of glucagon-like peptide-1 (GLP-1) and peptide YY (PYY). Clin. Nutr. 30:524-532.

Theodorakis, M. J., O. Carlson, S. Michopoulos, M. E. Doyle, M. Juhaszova, K. Petraki, and J. M. Egan. 2006. Human duodenal enteroendocrine cells: Source of both incretin peptides, GLP-1 and GIP. Am. J. Physiol. Endocrinol. Metab. 290:E550-E559.

Theurer, C. B. 1986. Grain processing effects on starch utilization by ruminants. J. Anim. Sci. 63:1649-1662.

Tsai, C. H., M. Hill, S. L. Asa, P. L. Brubaker, and D. J. Drucker. 1997. Intestinal growth promoting properties of glucagon like peptide-2 in mice. Am. J. Physiol. 273:E77-E84.
Walker, J. A., and D. L. Harmon. 1995. Influence of ruminal or abomasal starch hydrolysate infusion on pancreatic exocrine secretion and blood glucose and insulin concentrations in steers. J. Anim. Sci. 73:3766-3774.

Winnig, M., B. Bufe, and W. Meyerhof. 2005. Valine 738 and lysine 735 in the fifth transmembrane domain of rTas1r3 mediate insensitivity towards lactisole of the rat sweet taste receptor. BMC Neurosci. 6:22.

Wolffram, S., E. Eggenberger, and E. Scharrer. 1986. Kinetics of Dglucose and L-leucine transport into sheep and pig intestinal brush border membrane vesicles. Comp. Biochem. Physiol. A Comp. Physiol. 84:589-593.

Wood, I. S. 1995. PhD thesis, University of Wales, Aberystwyth, UK.

Wood, I. S., J. Dyer, R. R. Hofmann, and S. P. Shirazi-Beechey. 2000. Expression of the $\mathrm{Na}^{+}$/glucose co-transporter (SGLT1) in the intestine of domestic and wild ruminants. Pflügers. Arch. 441:155162.

Ye, J., G. Coulouris, I. Zaretskaya, I. Cutcutache, S. Rozen, and T. Madde. 2012. Primer-BLAST: A tool to design target-specific primers for polymerase chain reaction. BMC Bioinformatics $13: 134$.

Zhang, Z., Y. Zhou, L. Wagner, and W. Miller. 2000. A greedy algorithm for aligning DNA sequences. J. Comput. Biol. 7:203-214. 